\title{
Cooperating oncogenes converge to regulate cyclin/cdk complexes
}

\author{
Alison C. Lloyd, ${ }^{1}$ Frank Obermüller, ${ }^{1}$ Susan Staddon, ${ }^{1}$ Carolyn F. Barth, ${ }^{1}$ Martin McMahon, ${ }^{2}$ and \\ Hartmut Land ${ }^{1,3}$ \\ ${ }^{1}$ Imperial Cancer Research Fund (ICRF), Lincoln's Inn Fields, London WC2A 3PX, UK; ${ }^{2}$ DNAX Research Institute, \\ Palo Alto, California 94304 USA
}

\begin{abstract}
The cooperation of oncogenes in the transformation of primary rat Schwann cells is a strikingly synergistic process. We have explored the molecular mechanisms involved. Activation of an inducible Raf kinase results in morphologically transformed cells that are arrested in $G_{1}$ via the induction of $p^{2} 1^{\text {Cip1 }}$ and subsequent inhibition of cyclin/cdk activity. In contrast, coexpression of SV40 large T (LT) or a dominant-negative mutant of $\mathbf{p} 53$ abolishes $\mathbf{p} 21^{\text {Cip1 }}$ induction and alleviates the growth arrest. Moreover in this scenario, Raf activation results in an increase in the specific activity of cyclin/cdk complexes with Raf and LT cooperating to superinduce cyclin A/cdk2 activity and stimulate proliferation in the absence of mitogens. Thus, signaling by Raf and its cooperating partners converges at the regulation of cyclin/cdk complexes, with the cellular responses to Raf modulated by $\mathbf{p} 53$.
\end{abstract}

[Key Words: Cell cycle; oncogenes; cyclin-dependent kinase; p21 ${ }^{\text {Cip1 }}$; Raf; p53]

Received July 31, 1996; revised version accepted January 20, 1997.

Tumorigenesis is a multistep process involving the accumulation of genetic defects that contribute to the phenotype of the tumor. This is reflected by a large number of in vitro and in vivo studies that have shown that more than one oncogenic lesion is required to fully transform most primary cell types (for review, see Hunter 1991). However, the contribution of each oncogene to the transformed phenotype and the molecular mechanisms that underlie oncogene cooperation are poorly understood.

Primary rat Schwann cells are particularly suitable to study oncogene cooperation as homogenous cultures of these cells isolated from neonatal sciatic nerves can be cultured successfully in vitro for extended periods (Brockes et al. 1979). Previously we have shown that the cooperation of Ras and simian virus 40 large $T$ antigen (LT) in the transformation of primary Schwann cells is a synergistic process in which the cellular response to Ras is dependent on the presence of LT (Ridley et al. 1988). Introduction of activated Ras alone results in morphologically transformed cells that are growth-arrested and only when coexpressed with LT does Ras induce the formation of highly proliferative, anchorage-independent cultures. In contrast, LT alone lowers the growth factor requirement of cells that otherwise exhibit normal behavior.

The Ras signaling pathway in Schwann cells is of particular interest as activation of the Ras pathway through the loss of the GTPase activating protein neurofibromin

${ }^{3}$ Corresponding author.

E-MAIL land@icrf.icnet.uk; FAX 0171-269-3581. has been implicated in the common genetic disorder neurofibromatosis type 1 , a disease primarily affecting Schwann cells (Ballester et al. 1990; Martin et al. 1990; $\mathrm{Xu}$ et al. 1990a,b). Patients with this disorder frequently develop multiple benign neurofibromas, which are composed mainly of Schwann cells. They also have an increased risk of developing malignant tumors derived from Schwann cells or other neural crest-derived cell types. Inhibition of the Ras pathway in tumor cells derived from these patients, using either neutralizing antibodies to Ras or by increasing Ras-GAP activity, results in a reversion of the tumor cells, confirming the role of Ras in tumor formation in this disease (Basu et al. 1992; DeClue et al. 1992). In addition, transgenic animals in which LT expression is directed to Schwann cells develop neurocristopathies that resemble neurofibromatosis type I, demonstrating that LT expression can also contribute to the development of tumors in this cell type in vivo (Mazarakis et al. 1996).

To explore the molecular basis for the cooperation between Ras and LT we have used an inducible Raf protein in which an activated Raf kinase has been fused to the estrogen receptor hormone-binding domain ( $\triangle$ Raf-1:ER) (Samuels et al. 1993). Raf has been shown to act directly downstream of Ras (Moodie et al. 1993; Van Aelst et al. 1993; Voitek et al. 1993; Warne et al. 1993) and elicits a similar phenotype in some cell types; for example, in PC12 cells both activated Ras and Raf proteins are capable of inducing neurite outgrowth (Wood et al. 1993). In primary Schwann cells we show that the effects of Raf are indistinguishable from those of Ras. The use of $\Delta$ Raf- 
1:ER has allowed the biochemical analysis of signaling events in Schwann cells following Raf activation in the presence and absence of LT. We show that Raf and LT cooperate to regulate cyclin/cdk activity. Raf alone induces the cdk inhibitor $\mathrm{p} 21^{\mathrm{Cip} 1}$ by a p53-dependent mechanism, resulting in a cell cycle arrest. In cells in which $\mathrm{p} 21^{\text {Cip } 1}$ induction is counteracted by the expression of dominant-negative p53 or LT, Raf increases the specific activity of cyclin/cdk complexes with Raf and LT signals cooperating to superinduce cyclin A/cdk 2 activity and stimulate proliferation of the transformed cells.

\section{Results}

Raf alters Schwann cell morphology and causes $G_{1}$ arrest

To facilitate the analysis of Ras and LT cooperation in primary Schwann cells we exploited the $\Delta$ Raf-1:ER system. This Raf/estrogen receptor fusion protein ( $\Delta$ Raf$1: E R)$ exhibits kinase and transforming activity in a strictly hormone-dependent fashion (Samuels et al. 1993). Low passage normal rat Schwann cells were infected with the retroviral vector LXSN (Miller and Rosman 1989) or its derivative LXSN- $\Delta$ Raf-1:ER. Several hundred G418 resistant colonies infected with the empty vector (NSE) or the vector encoding the inducible Raf protein (NS $\triangle$ RafER) were pooled and expanded. The growth properties of these cells were maintained over several months, such that the cells did not appear to enter crisis or show any significant changes in their ability to quiesce or respond to mitogenic signals. Early passage NS $\triangle$ RafER cells were then infected with a second retroviral vector, Babe-Puro (Morgenstern and Land 1990 ) or with the Babe-Puro vector expressing SV40 LT. Puromycin-resistant colonies expressing both $\triangle$ Raf-1:ER and LT (NSARafERLT) or $\triangle$ Raf-1:ER and the empty vector (NSARafERBp) were pooled and expanded.

The addition of 4-hydroxy-tamoxifen (TMX) to the NS $\triangle$ RafER cells resulted in a dramatic change in cell morphology (Fig. 1A). When viewed by time-lapse video microscopy, elongation of the normally flat cells could be seen as early as $6 \mathrm{hr}$. In addition to the cells exhibiting a highly refractile phenotype, they also extended processes and became more motile. This motility was not inhibited by cell-cell contact as the cells would move across each other. These morphological changes were indistinguishable from those seen when Schwann cells are injected with Ras protein (Ridley et al. 1988) or those reported in Schwann cells isolated from late-stage embryos with a homozygous deletion of the NF1 gene (Kim et al. 1995). The activation of Raf in the cells coexpressing LT (NSARafERLT) led to similar morphological changes and increased cell motility, whereas the addition of TMX to Schwann cells expressing the empty LXSN vector (NSE) had no detectable effects on the morphology of the cells (data not shown).

In order to address the effects of the activation of $\Delta$ Raf-
1:ER on the proliferation of normal Schwann cells, the cells were analyzed for bromodeoxyuridine (BrdU) incorporation and DNA content by flow cytometry. The addition of TMX to the NS $\triangle$ RafER cells resulted in a cell cycle arrest in the $G_{1}$ phase of the cell cycle, whereas TMX had no effect on the cell cycle profile of the control NSE cells (Fig. 1B). This inhibition of cell growth was confirmed by ${ }^{3} \mathrm{H}$-thymidine uptake assays, which showed a $\sim 80 \%$ decrease in DNA synthesis (Fig. 1C, right). When the cells were followed by time-lapse microscopy a complete cessation of cell division was observed within $30 \mathrm{hr}$. This was not associated with any observable cell death during the $72 \mathrm{hr}$ of the experiment (data not shown). Our previous results showed that Ras induced both $a G_{1}$ and $G_{2}$ arrest in Schwann cells (Ridley et al. 1988). However, these experiments were carried out in cells coexpressing a temperature-sensitive LT and it is possible that the $G_{2}$ arrest is attributable to the removal of LT from cells cultured habitually in the presence of LT (Gonos et al. 1996). In contrast to cells expressing $\triangle$ Raf-1:ER alone, cells coexpressing LT (NSARafERLT) were not inhibited in response to the activation of $\triangle$ Raf-1:ER; indeed, $\Delta$ Raf-1:ER increased the rate of DNA synthesis (Fig. 1C, right). The mitogenic effect of Raf in the NS $\triangle$ RafERLT cells was seen more clearly when the cells were incubated in Dulbecco's modified Eagle medium (DMEM) containing 2\% FCS without glial growth factor (GGF) or forskolin, conditions in which the NS $\Delta$ RafER cells quiesce and the LT cells grow more slowly (Fig. 1C, left). Under these conditions, addition of TMX to the NS $\triangle$ RafERLT cells led to a greater than three-fold increase in the rate of DNA synthesis as measured by ${ }^{3} \mathrm{H}$-thymidine uptake. The activation of $\triangle$ Raf-1:ER had no significant effect on DNA synthesis in the quiescent NS $\Delta$ RafER cells (Fig 1C, left).

Thus, Raf behaves similarly to Ras in Schwann cells by inducing distinct morphological changes and a cell cycle arrest. As with Ras, the cell cycle block induced by Raf is overcome by coexpressing LT and in this scenario the Raf signal is reinterpreted as a mitogenic stimulus. This would suggest that in Schwann cells it is the Raf signaling pathway that is responsible for both Ras-induced morphological transformation and the effects of Ras on the cell cycle.

\section{Constitutive activation of MAP kinase by $\triangle R$ af-1:ER in Schwann cells}

As an indicator of the activation of signaling pathways downstream from Raf, we compared the kinetics of mitogen-activated protein (MAP) kinase activation following mitogen stimulation in the presence and absence of activated $\Delta$ Raf-1:ER. Treatment of quiescent NS $\Delta$ RafER cells with mitogens resulted in a transient activation of p42-ERK-2, as measured by either a phosphorylation-dependent mobility shift that has been shown to be characteristic for MAP kinase activity (Fig. 1D) or an in vitro kinase assay (data not shown). In contrast, the addition of TMX to the NS $\triangle$ RafER cells in the presence (Fig. 1D) or absence (not shown) of exogenous mitogens resulted 
A

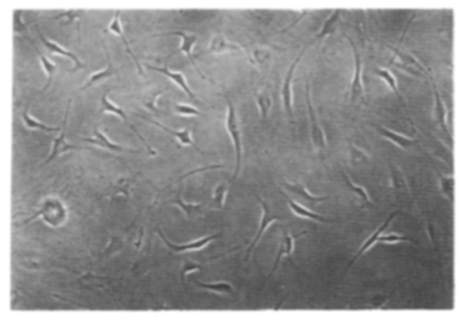

- TMX

B
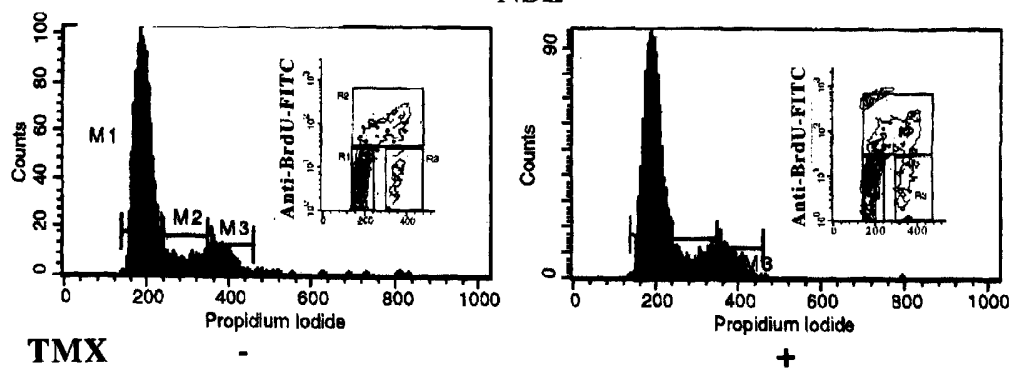

NSARafER

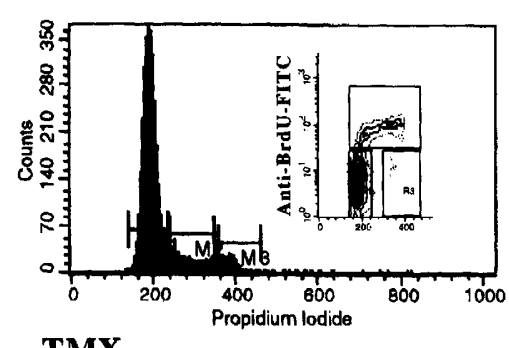

TMX

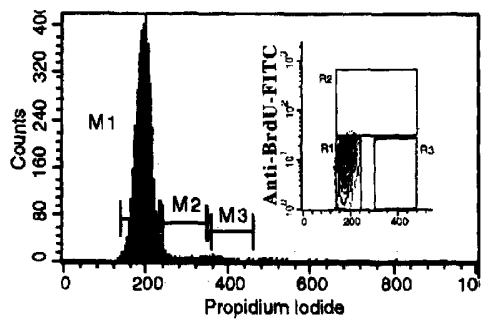

$+$
C

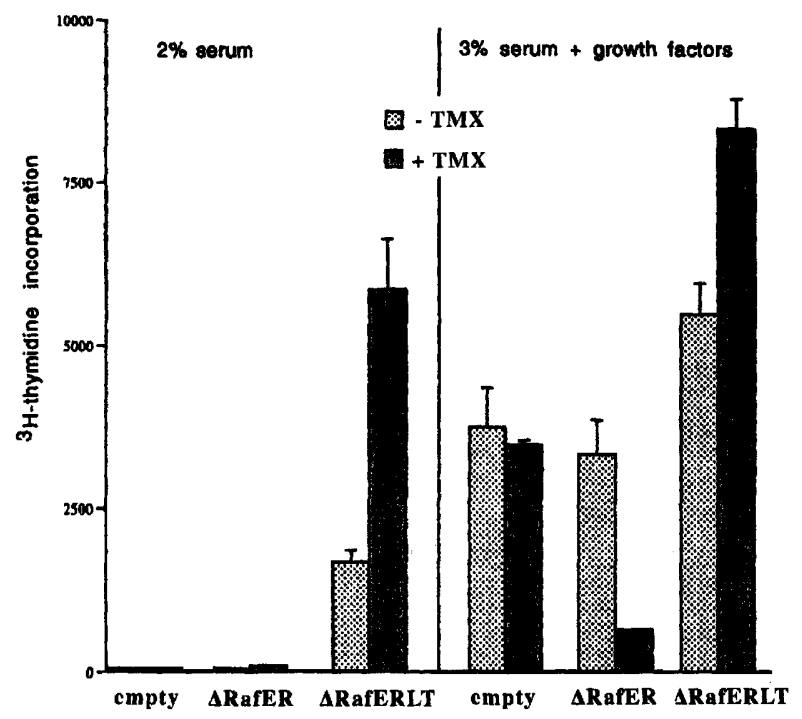

D

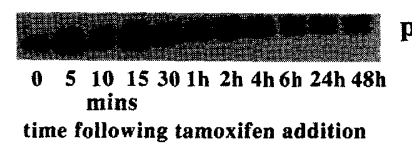

p42-ERK-2
NSE

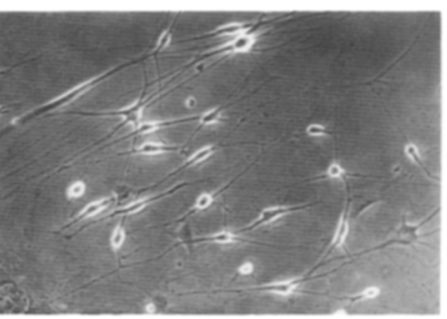

+ TMX

$+$ 
in the prolonged activation of p42-ERK-2. It therefore appears that the constitutive activity of $\triangle \mathrm{Raf}-1: E R$, which results in a cell cycle arrest, is overriding the growth-promoting signals by the mitogens. The activation of $\triangle$ Rafl-1:ER in cells coexpressing LT (NSARafERLT) also led to the prolonged activation of p42-ERK-2, with kinetics indistinguishable from those seen in the NS $\triangle$ RafER cells (not shown). Thus depending on the presence of LT, a constitutive Raf signal has opposing effects on the cell cycle.

\section{Raf arrests Schwann cells prior to induction of cyclin A}

To investigate the mechanism by which Raf causes a cell cycle arrest and how this is overcome in the NS $\triangle$ RafERLT cells, we decided to study the effects of Raf on cyclin/cdk activity. In an initial experiment, we addressed whether the activation of Raf was capable of blocking NS $\triangle$ RafER cells from entering the first S phase following growth factor stimulation of quiescent cells, as this would enable us to analyze the effects of Raf in a synchronized cell population. Subconfluent NSARafER cells were rendered quiescent by incubating them in medium containing $2 \%$ FCS for 2 days. Pulse-labeling with ${ }^{3} \mathrm{H}$-thymidine showed that entry into $\mathrm{S}$ phase occurred 16-20 hr following mitogen addition with a peak of DNA synthesis between 20 and $28 \mathrm{hr}$ (Fig. 2A). The coaddition of TMX resulted in a $\sim 80 \%$ decrease in the proportion of cells reaching the first $S$ phase. This inhibition was not attributable to a delay in the cells entering $S$ phase because further incubation did not lead to a significant increase in the incorporation of ${ }^{3} \mathrm{H}$-thymidine in cells treated with TMX, whereas the untreated cells continued to cycle (not shown).

To determine whether this $\Delta$ Raf-induced arrest was linked to changes in cyclin or cdk expression, cell lysates were prepared at various time points and analyzed by immunoblotting. Cyclin D1 levels were very low in the quiescent cells (Fig. 2B) and were induced as the cells entered $G_{1}$. In the presence of TMX, the levels of cyclin D1 were superinduced. This induction is not dependent on the presence of growth factors as it can be seen in the absence of factor addition with similar kinetics (data not shown). Other studies have reported that Ras and Raf expression and transformation leads to a marked elevation of cyclin D1 levels in immortalized rodent fibroblasts (Liu et al. 1995; Winston et al. 1996). Our results demonstrate that the activation of the Raf pathway is sufficient to induce cyclin D1 in nonestablished cells. Cyclin E levels appeared to be invariant as the cells progressed from the quiescent state through $G_{1}$ and were unaffected by the activation of $\triangle$ Raf-1:ER, suggesting that modulation of cyclin E levels is not the principal mechanism controlling cell cycle progression in primary Schwann cells. Cyclin A protein, although present in significant amounts in the quiescent cells, was induced as the cells progressed toward and entered S phase. However, in the cells treated with TMX, this induction of cyclin A was not seen (Fig. 2B). Cdk4 expression in-
$\mathbf{A}$

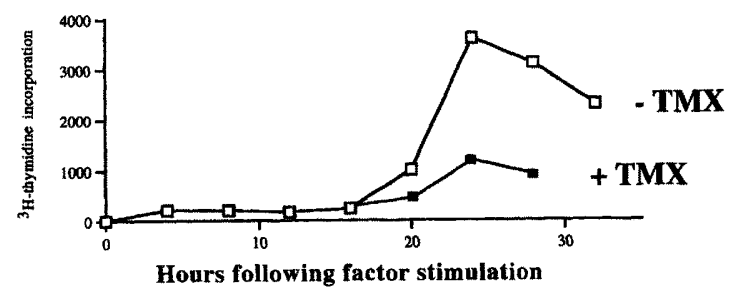

$\mathbf{B}$

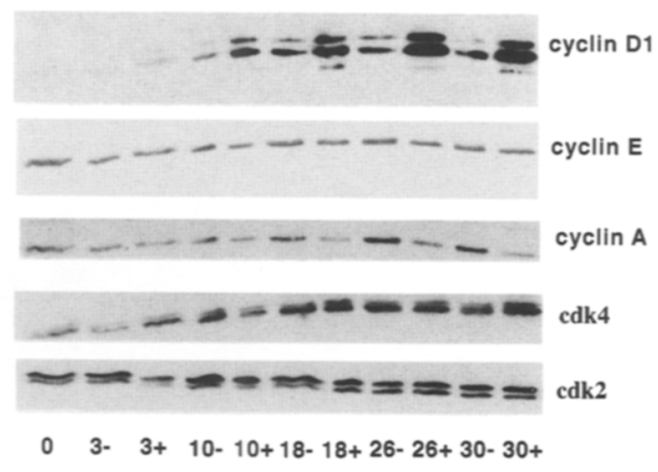

Hours following factor stimulation (- $/+$ TMX )

Figure 2. Raf arrests Schwann cells in $\mathrm{G}_{1}$ prior to the induction of cyclin A. (A) NSARafER cells were quiesced for $48 \mathrm{hr}$ in DMEM supplemented with $2 \%$ FCS. The cells were stimulated with fresh medium supplemented with forskolin and GGF in the presence or absence of $200 \mathrm{nM}$ TMX. The cells were pulselabeled with $\left[{ }^{3} \mathrm{H}\right]$ thymidine at four hourly intervals and TCAprecipitable material was filtered and counted in a scintillation counter. $(B)$ Protein lysates were prepared at the time points indicated and were analyzed by Western blotting with antibodies specific for the indicated proteins.

creased slightly during $\mathrm{G}_{0} / \mathrm{G}_{1}$ progression, whereas cdk2 levels remained relatively unchanged. However, neither cdk4 nor cdk2 levels appeared to be affected by $\Delta$ Raf1:ER activation. These results suggest that activation of $\Delta$ Raf-1:ER leads to a cell cycle arrest in $G_{1}$ prior to the induction of cyclin A.

\section{Raf inhibits cyclin $E$ - and cyclin $A$-dependent kinase activity}

The finding that the block in $G_{1}$ appeared to occur prior to the induction of cyclin A was also reflected by the low levels of cyclin A protein observed when growing cells were arrested by activation of $\Delta$ Raf-1:ER (Fig. 3A, top left). Immunoprecipitation of cyclin A complexes from these cells showed that there was a corresponding decrease in cyclin $\mathrm{A} / \mathrm{cdk} 2$ complexes (Fig. $3 \mathrm{~A}$, top right) and cyclin A-dependent kinase activity (Fig. 3A, bottom). It appears that in Schwann cells, virtually all the cdk2 associated with cyclin $\mathrm{A}$ is the faster migrating isoform of $\operatorname{cdk} 2$, which has been shown to correspond to the ac- 
$\mathbf{A}$

cyclin A IP

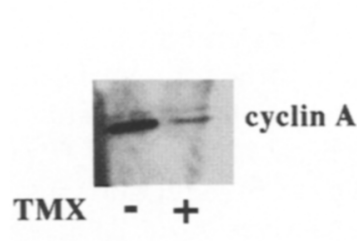

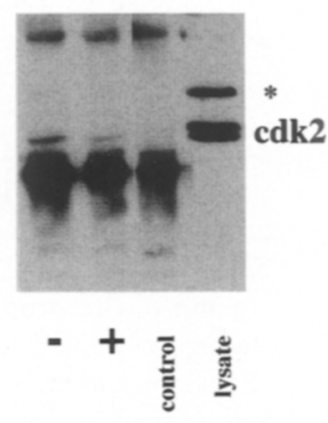

cyclin A-dependent kinase activity

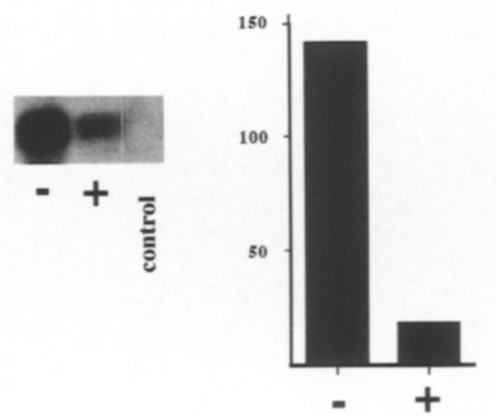

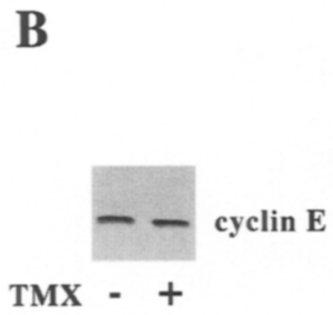

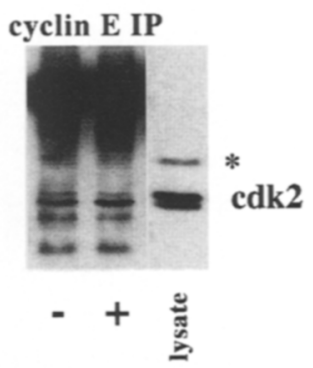

cyclin E-dependent kinase activity

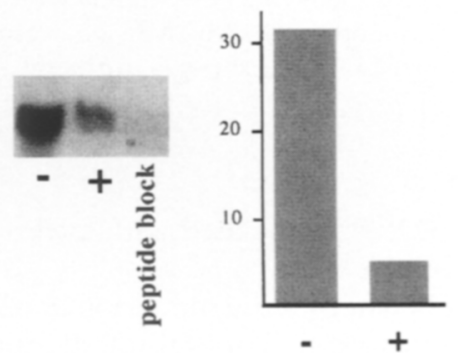

Figure 3. Raf activation inhibits cyclin A- and cyclin E-dependent kinase activity. Asynchronously growing NS $\Delta$ RafER cells were cultured in the presence $(+)$ or absence $(-)$ of $200 \mathrm{nM}$ TMX for $30 \mathrm{hr}$. Protein lysates were prepared and standardized for protein content. $(A, B$ topleft $)($ left $)$ Western analysis for cyclin $\mathrm{A}(A)$ and cyclin $\mathrm{E}(B)$. Lysates $(100-300 \mu \mathrm{g})$ were subjected to immunoprecipitation with a cyclin A monoclonal antibody $(A)$ or a cyclin $\mathrm{E}$ antibody $(B)$. The controls were protein $\mathrm{G}-\mathrm{Sepharose}$ beads alone for the cyclin $\mathrm{A}$ antibody or a peptide block for the cyclin $\mathrm{E}$ antibody. The immunoprecipitates were either Western blotted with a cdk2 antibody (top right) or assayed for histone $\mathrm{H} 1$ kinase activity (bottom). $\left(^{\star}\right.$ ) Alternative spliced form of cdk2 seen in rodent cells (Matsushime et al. 1994).

tive form phosphorylated on residue Thr-160/Gu et al. 1992). This may reflect high CDK-activating kinase (CAK) activity in Schwann cells or possibly a preferential association of cyclin $\mathrm{A}$ with the activated kinase.

Unlike cyclin A, cyclin E levels were unaffected by activation of $\triangle$ Raf-1:ER (Fig. 3B, top left). Moreover, immunoprecipitation of cyclin $\mathrm{E}$ complexes from both growing and arrested NS $\triangle$ RafER cells showed that there were similar levels of cyclin E/cdk2 complexes in the growing and arrested cells (Fig. 3B, top right). The cdk2 complexed to cyclin $\mathrm{E}$, as for the cyclin A complexes, was mostly the CAK-phosphorylated form. Interestingly, however, the cyclin E-dependent kinase activity associated with these complexes was reduced almost to background levels in the arrested cells (Fig. 3B, bottom). Thus, activation of Raf leads to a dramatic decrease in the specific activity of cyclin $\mathrm{E} / \mathrm{cdk}$ complexes. The loss of both cyclin $\mathrm{E}$ and cyclin A-dependent kinase activities in the arrested cells was reflected by a similar inhibition of cdk2 precipitable $\mathrm{H} 1$ kinase activity (data not shown). Cyclin E, cyclin A, and cdk2 activity have each been shown to be required for entry into $S$ phase /Girard et al. 1991; Pagano et al. 1992; Zindy et al. 1992; Tsai et al. 1993; van den Heuvel and Harlow 1993; Ohtsubo et al.
1995). Therefore it is likely that the inhibition of these cyclin/cdk complexes is sufficient to arrest the cells in $\mathrm{G}_{1}$.

\section{Raf induces $p 21^{\text {Cip } 1}$ expression}

Because cyclin $\mathrm{E} / \mathrm{cdk} 2$ activity was reduced without a concomitant decrease in the expression of the proteins, we investigated whether Raf induction affected the expression of cdk inhibitors, such as $\mathrm{p} 21^{\text {Cip } 1}$ (el-Deiry et al. 1993; Harper et al. 1993; Xiong et al. 1993; Noda et al. 1994) and p27 ${ }^{\text {Kip1 }}$ (Polyak et al. 1994; Toyoshima and Hunter 1994). Lysates were prepared from NS $\triangle$ RafER cells grown in the presence or absence of TMX and the inhibitor levels were analyzed by Western blotting. Activation of Raf had no effect on $\mathrm{p} 27^{\mathrm{Kip} 1}$ levels (Fig. 4A). However, Raf activation induced a large increase in the levels of $\mathrm{p}^{2} 1^{\mathrm{Cip} 1}$ (Fig. 4B). The addition of TMX to the control NSE cells had no effect on the levels of $\mathrm{p} 21^{\mathrm{Cip} 1}$ (data not shown). Samples of each lysate were also immunoprecipitated with cyclin $\mathrm{E}$ antibodies and the precipitated proteins were immunoblottted with $\mathrm{p} 21^{\text {Cip } 1}$ antibodies. Figure $4 \mathrm{C}$ shows that the induction of Raf in the NS $\triangle$ RafER cells resulted in a corresponding increase 


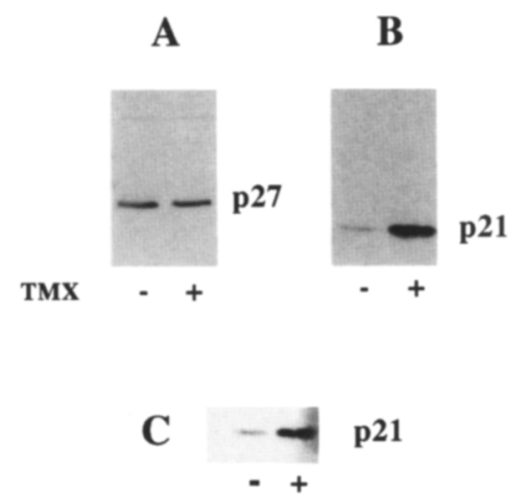

Figure 4. Activation of Raf leads to an increase in $\mathrm{p} 21^{\mathrm{Cip} 1}$. NS $\Delta$ RafER cells were grown for $30 \mathrm{hr}$ in the presence of $\mathrm{TMX}(+)$ or the solvent control $(-)$. Thirty micrograms of protein lysates was subjected to immunoblot analysis with an anti-p27 antibody $(A)$ or an anti-p21 antibody $(B)$. Three hundred micrograms of the lysates was immunoprecipitated with the cyclin $\mathrm{E}$ antibody and Western blotted with an anti-p21 antibody.

in the amount of $\mathrm{p} 21^{\mathrm{Cip} 1}$ associated with cyclin E complexes.

To further address whether the induction of $\mathrm{p} 21^{\mathrm{Cip} 1}$ is responsible for the suppression of cyclin E-dependent kinase activity and the inhibition of DNA synthesis in Raf-arrested cells, we determined the kinetics of these three events. The rate of the $\triangle$ Raf-1:ER-induced inhibition of DNA synthesis was analyzed by measuring the incorporation of ${ }^{3} \mathrm{H}$-thymidine in NS $\Delta$ RafER cells pulselabeled at various time points. These experiments showed that the growth inhibition induced by $\Delta$ Raf-1:ER commenced after a 12-hr lag period with significant decreases in $\left[{ }^{3} \mathrm{H}\right]$ thymidine uptake apparent after $14 \mathrm{hr}$ and complete inhibition after $24 \mathrm{hr}$ (Fig. 5A). The late onset of the growth arrest induced by $\Delta$ Raf-1:ER was paralleled by a similar delay in the induction of $\mathrm{p}^{2} 1^{\mathrm{Cip} 1}$, with a small increase seen at $10 \mathrm{hr}$ and maximal induction at $\sim 22 \mathrm{hr}$ (Fig. 5B). This delayed appearance of $\mathrm{p} 21^{\mathrm{Cipl}}$ was in contrast to the rapid induction of cyclin Dl, which could be seen as early as $3 \mathrm{hr}$ following TMX addition to growing (not shown) or quiescent cells (Fig. 2B). The decrease in cyclin E-dependent kinase activity coincided with the induction of $\mathrm{p} 21^{\mathrm{Cip} 1}$ and preceded the inhibition of DNA synthesis (Fig. $5 \mathrm{~A}$ ), arguing that $\mathrm{p} 21^{\mathrm{Cip} 1}$ is responsible for the inhibition of the kinase activity that results in the growth arrest of the cells.

\section{Raf induction of $p 21^{\text {Cip } 1}$ and cell cycle arrest are $p 53$ dependent}

Schwann cells coexpressing $\triangle$ Raf-1:ER and LT (NSARafERLT) no longer arrest in response to $\triangle$ Raf-1:ER activation. Although it has been reported that LT can counteract the inhibitory effect of $\mathrm{p} 21^{\mathrm{Cipl}}$ in cotransfection experiments (Harper et al. 1993), we were interested to explore whether $\Delta$ Raf-1:ER would induce p21 ${ }^{\text {Cipl } 1}$ in these cells. Pools of NSARafERLT cells and control
NS $\triangle$ RafERBp cells were grown for $30 \mathrm{hr}$ in the presence or absence of TMX. Lysates prepared from these cells were then subjected to Western blot analysis to detect p $21^{\text {Cip } 1}$. We found that although $\Delta$ Raf-1:ER induced p $21^{\text {Cip } 1}$ in the control cells, LT coexpression resulted in both a decrease in the basal level of $\mathrm{p} 21^{\mathrm{Cip} 1}$ expression and an apparent loss of $\mathrm{p} 21^{\mathrm{Cip} 1}$ induction (Fig. 6A). Thus, in LT expressing cells, activation of $\triangle$ Raf-1:ER can no longer elevate $\mathrm{p} 21^{\mathrm{Cip} 1}$ levels.

One of the properties of LT is that it can bind to and sequester p53 (Lane and Crawford 1980; Maltzman et al. 1981). p53 is known to control the regulation of $\mathrm{p} 21^{\text {Cip } 1}$ expression (el-Deiry et al. 1993; Li et al. 1994; Liu et al. 1995; Macleod et al. 1995) and in recent experiments it has been shown that embryonic fibroblasts isolated from p21-/- mice and a colon cancer cell line with a homozygous deletion of the $\mathrm{p} 21$ gene are significantly or com-

\section{A}

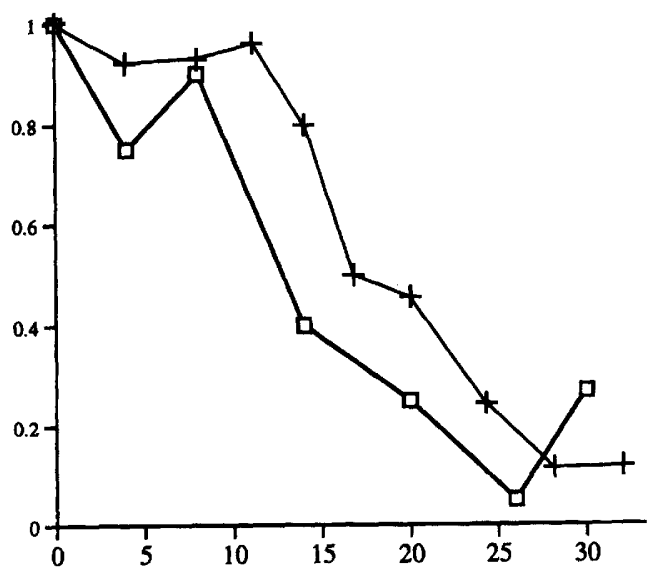

Hours following tamoxifen addition

B

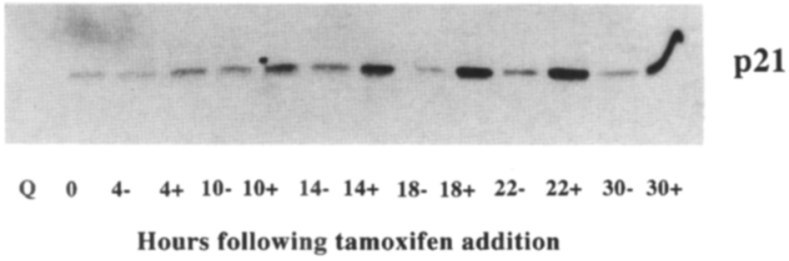

Figure 5. The kinetics of $\mathrm{p} 21^{\mathrm{Cip} 1}$ induction, cyclin E-dependent kinase activity, and DNA synthesis following Raf activation. Asynchronously growing NS $\triangle$ RafER cells were incubated in the presence of TMX $(+)$ or control solvent $(-) .(A)(\square)$ Protein lysates were prepared at the times indicated. Three hundred micrograms of the lysates was immunoprecipitated with an anti-cyclin $\mathrm{E}$ antibody and assayed for histone $\mathrm{H} 1$ kinase activity. $(+)$ DNA synthesis was measured by the uptake of $\left[{ }^{3} \mathrm{H}\right]$ thymidine added between the times indicated. The results are expressed as the amount of activity relative to the corresponding control activity. $(B)$ Protein lysates were prepared at the indicated time points or from quiescent NS $\Delta$ RafER cells $(Q)$ and were subjected to immunoblotting analysis with an anti-p21 antibody. 

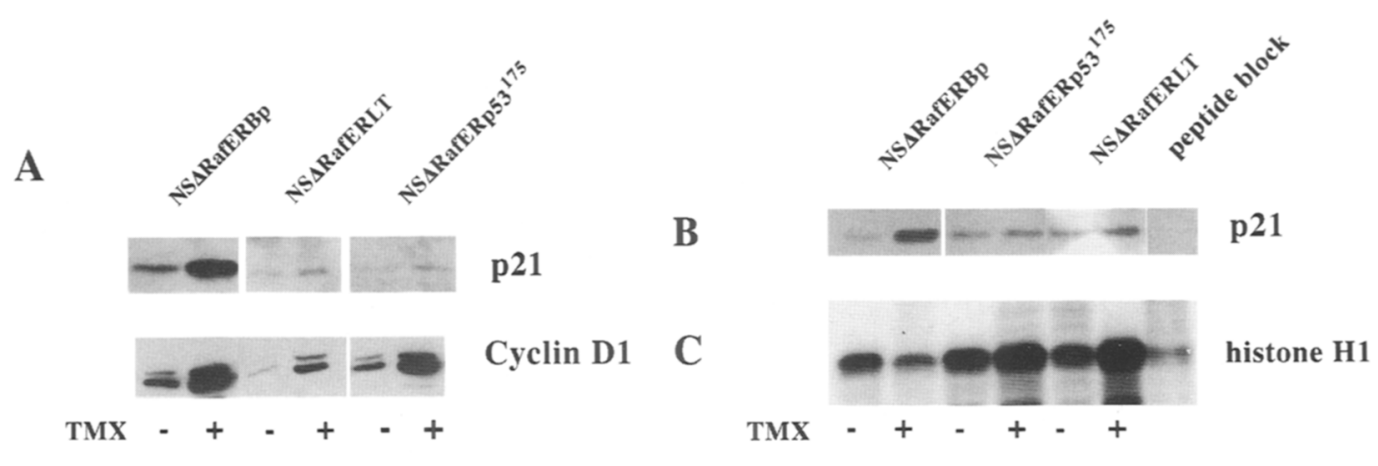

D
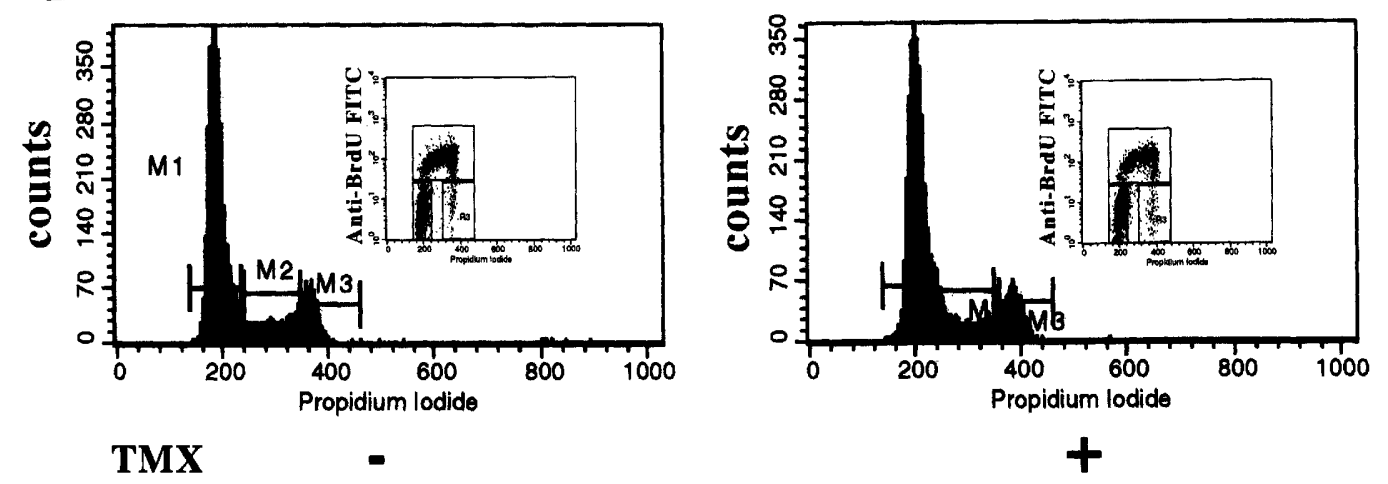

Figure 6. The induction of $\mathrm{p} 21^{\mathrm{Cip} 1}$ in Raf-arrested cells is p53-dependent. NS $\Delta$ RafER cells were infected with retroviral vectors expressing a dominant-negative form of p53 (p53 $\left.{ }^{175}\right)$. Pools of NS $\Delta$ RafERBp, NS $\Delta$ RafERp $53^{175}$, and NS $\Delta$ RafERLT cells were grown in the presence of TMX $(+)$ or the control solvent $(-)$ for $30 \mathrm{hr}$. $(A)$ Protein lysates were prepared and analyzed by Western blotting with an anti-p21 antibody or an anti-cyclin D1 antibody as indicated. $(B, C)$ Three hundred micrograms of lysates was immunoprecipitated with an anti-cyclin E antibody and then $(B)$ analyzed by Western blotting with an anti-p2 $1^{\text {Cipl } 1}$ antibody or $(C)$ assayed for histone $\mathrm{H} 1$ kinase activity. $(D)$ The NS $\Delta$ RafERp $53^{175}$ cells were trypsinized and analyzed for DNA content by propidium iodide staining and flow cytometry and for BrdU incorporation in the $4 \mathrm{hr}$ prior to trypsinization (see insets).

pletely deficient in their ability to arrest in $G_{1}$ in response to p53-dependent growth inhibitory signals (Brugarolas et al. 1995; Deng et al. 1995; Waldman et al. 1995|. Therefore, we were interested in whether the induction of $\mathrm{p} 21^{\mathrm{Cip} 1}$ in response to Raf was p53-dependent and whether inactivation of p53 was capable of abolishing the $\Delta$ Raf-1:ER-induced growth arrest. NS $\Delta$ RafER cells were infected with a Babe-Puro retroviral vector constructed to encode a dominant negative mutant $(\mathrm{dn})$ of $\mathrm{p} 53\left(\mathrm{p} 53^{175}\right)$, which has been shown to inhibit the activity of endogenous p53 (Kern et al. 1992). Puromycin-resistant colonies were pooled and expanded. Proliferating NS $\Delta$ RafERp $53^{175}$ were incubated in the presence or absence of TMX. Lysates were prepared and FACS analysis was carried out on the cells $30 \mathrm{hr}$ after the addition of hormone. Immunoblot analysis of the lysates showed that as with the LT-expressing cells, the basal levels of $\mathrm{p} 21^{\mathrm{Cipl}}$ expression were reduced in the cells expressing a dominant-negative mutant of p53 (dn-p53) and $\triangle$ Raf-1:ER activation no longer stimulated a significant induction of $\mathrm{p} 21^{\mathrm{Cip} 1}$ (Fig. 6A). Consistent with this finding, equivalent levels of $\mathrm{p} 21^{\mathrm{Cip} 1}$ were precipitated by cyclin $\mathrm{E}$ antibodies from the same lysates (Fig. 6B). Simi- lar results were obtained with NS $\Delta$ RafER cells infected with a retrovirus expressing the carboxy-terminal oligomerization domain of p53 (data not shown). Thus $\Delta$ Raf1 :ER induction of $\mathrm{p} 21^{\mathrm{Cip} 1}$ in Schwann cells is $\mathrm{p} 53$ dependent.

Cyclin D1 induction by $\Delta$ Raf-1:ER, unlike $\mathrm{p} 21^{\text {Cipl, }}$, does not appear to be p53-dependent. Immunoblot analysis of lysates of the NS $\Delta$ RafERp $53^{175}$ cells showed that Raf stimulated a large induction of cyclin D1, similar to that seen in the parental cells (Fig. 6A). This observation demonstrates that p53 is required only for a specific subset of Raf signals and suggests that the levels of cyclin D1 induced by Raf are unlikely to be involved in the growth arrest of these cells. Cyclin D1 levels are lower in NSARafERLT cells, a finding consistent with other reports that have shown that RB-binding proteins such as LT down-regulate cyclin D1 expression and these cells no longer require cyclin D1 function to cycle (Lukas et al. 1994). Raf activation is still able to stimulate cyclin D1 expression in these cells but only to levels found in the uninduced NS $\triangle$ RafER cells (Fig. 6A), indicating that the pathway required for cyclin D1 induction remains active in LT-expressing cells. 
Cyclin E-dependent kinase assays performed on aliquots of lysates from NS $\triangle$ RafERp $53^{175}$ showed that in the presence of dn-p53, $\triangle$ Raf-1:ER no longer inhibited the kinase activity but instead stimulated a two-fold increase in kinase activity (Fig. 6C). Likewise, in the NS $\triangle$ RafERLT cells Raf also stimulated an increase in cyclin E-dependent kinase activity. Thus, in the absence of $\mathrm{p} 21^{\text {Cipl } 1}$ induction, signals from Raf increase cyclin E-dependent kinase activity.

FACS analysis of the NSARafERp $53^{175}$ cells showed that their cycling was unaffected by $\Delta$ Raf-1:ER activation (Fig. 6D), demonstrating that the Raf-induced growth arrest is dependent on normal p53 function. This finding indicates that the increase in cyclin E-dependent kinase activity stimulated by Raf is not the result of increased cell cycling and is thus likely to be a more direct effect of Raf activation. These results would also suggest that the elvation in cyclin D levels and the increased cyclin E-dependent kinase activity are not sufficient to effect the cell cycle distribution of these cells.

\section{Induction of $p 21^{\text {Cip } 1}$ is necessary for Raf-induced cell cycle arrest}

We have shown that the induction of $\mathrm{p} 21^{\mathrm{Cip} 1}$ by Raf is p53-dependent. As it has been shown previously that p21 ${ }^{\text {Cip } 1}$ is at least partly responsible for the $G_{1}$ arrest in response to $\mathrm{p} 53$-dependent radiation damage (Brugarolas et al. 1995; Deng et al. 1995; Waldman et al. 1995), we

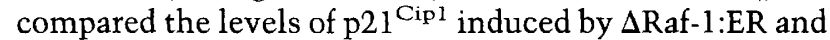
$\gamma$-irradiation in primary Schwann cells. NS $\Delta$ RafER cells were treated with either 5 Gy $\gamma$-irradiation or TMX. $\left[{ }^{3} \mathrm{H}\right]$ thymidine-uptake assays showed that this led to a $75 \%$ and $80 \%$ inhibition of DNA synthesis, respectively. As expected, NSARafERp $53^{175}$ cells were mostly protected from the inhibition of DNA synthesis induced by $\gamma$-irradiation or TMX with only a $24 \%$ and $3 \%$ inhibition of DNA synthesis seen in these cells, respectively. Western analysis of lysates prepared from parallel plates showed that the levels of $\mathrm{p} 21^{\mathrm{Cipl}}$ induced by $\Delta$ Raf-1:ER were equivalent to those induced by $\gamma$-irradiation (Fig. $7 \mathrm{~A})$ and that the induction was reduced greatly in the cells expressing dn-p53. Thus the levels of $\mathrm{p} 21^{\text {Cipl }}$ induced by Raf are likely to be sufficient to arrest the cells.

To further test the role of $\mathrm{p} 21^{\text {Cip1 }}$ in the growth arrest elicited by Raf we attempted to reduce the induction of $\mathrm{p} 21^{\mathrm{Cip} 1}$ by expression of antisense RNA. NS $\Delta$ RafER cells were infected with the Babe-Puro retrovirus constructed to express rat $\mathrm{p} 21$ antisense RNA. Puromycin-resistant colonies were picked and expanded. At all times the clones were grown in conditioned medium from confluent dishes of Schwann cells, as this allowed the expansion of the clones. Two out of 10 clones tested, 7 and 9, showed a greatly reduced ability to arrest in response to Raf activation as measured by $\left[{ }^{3} \mathrm{H}\right]$-thymidine uptake assays compared with clones that arrested (Fig. 7B) or cells infected with the empty vector (not shown), despite being morphologically transformed. Western blot analysis of clones 7 and 9 showed that both expressed $\Delta$ Raf-1:ER at levels comparable to those of clones that arrested,
A

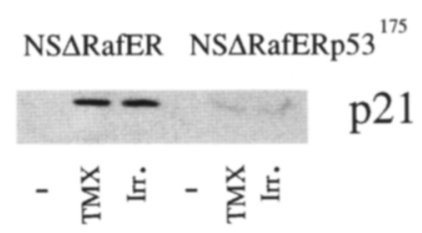

B

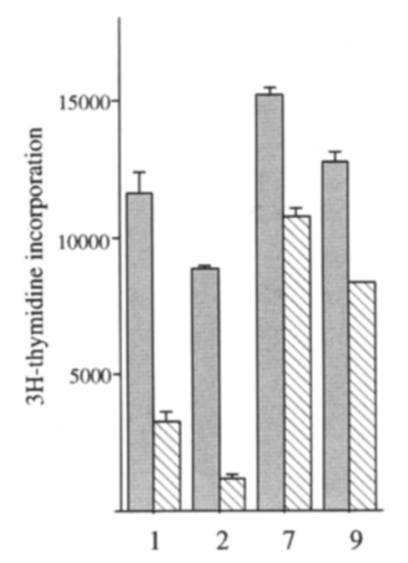

C

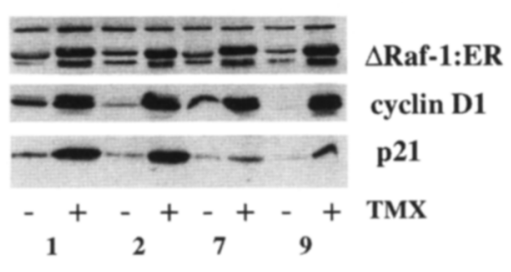

D

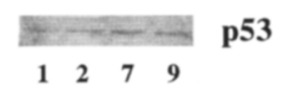

Figure 7. Induction of $\mathrm{p} 21^{\mathrm{Cipl}}$ is responsible for the $\mathrm{G}_{1}$ arrest. (A) Preconfluent NS $\triangle$ RafER and NS $\triangle$ RafERp $53^{175}$ cells were treated with either $200 \mathrm{nM}$ TMX or 5 Gy of $\gamma$-irradiation. Lysates were prepared $24 \mathrm{hr}$ following stimulation. Thirty micrograms of protein lysates were subjected to immunoblot analysis with an anti-p21 antibody. $(B)$ NS $\Delta$ RafER cells were infected with the Babe-Puro retroviral vector constructed to express antisense rat p21 mRNA. Clones were picked and expanded. $\left[{ }^{3} \mathrm{H}\right]$ Thymidine was added $20 \mathrm{hr}$ following tamoxifen addition. At $30 \mathrm{hr}$ the cells were lysed. TCA precipitated material was filtered and counted. The results for clones 1,2,7, and 9 are shown. (C) Cell lysates of clones $1,2,7$, and 9 were prepared 26 $\mathrm{hr}$ following the addition of ethanol $(-)$ or TMX $(+)$ to growing cells. Thirty micrograms of protein was analyzed by Western blotting with an anti-hER, anti-cyclin D1, or anti-p21 antibody as indicated. $(D)$ Cell lysates of clones $1,2,7$, and $9(30 \mu \mathrm{g}$ protein) were analyzed by Western blotting with an anti-p53 antibody.

with the levels being induced to a similar extent by the addition of tamoxifen (Fig. 7C) as reported previously (Samuels et al. 1993). Cyclin D1 expression was also induced to a similar extent in clones 7 and 9 when compared with arresting clones (Fig. 7C) or with cells expressing empty vector (not shown). These results dem- 
onstrate that Raf appears to be similarly active in all four clones in response to tamoxifen. However, in both clones 7 and 9 the ability of $\triangle$ Raf-1:ER activation to induce $\mathrm{p} 21^{\mathrm{Cip} 1}$ levels was specifically attenuated (Fig. 7C). This phenotype is similar to cells expressing mutant p53. We therefore compared the p53 status of the four clones. As shown in Figure 7D, the clones express similar levels of $\mathrm{p} 53$. Because mutant $\mathrm{p} 53$ proteins are more stable than their wild-type counterparts (Finlay et al. 1988; Harvey and Levine 1991), this indicates that all clones express normal p53. Taken together, these results support the idea that $\mathrm{p} 21^{\mathrm{Cip} 1}$ induction is responsible for the $\mathrm{G}_{1}$ cell cycle arrest induced by Raf, although we cannot rule out other mechanisms contributing to the partial inhibition still seen in clones 7 and 9 .

\section{Raf and LT cooperate to increase cyclin A/cdk2 activity and induce DNA synthesis}

Although Schwann cells expressing dn-p53 do not arrest in response to $\Delta$ Raf-1:ER, it is only in LT-expressing Schwann cells that $\Delta$ Raf-1:ER causes an increase in cell cycling. This indicates that in addition to inhibiting p53 activity, LT has additional effects on the cell cycle (Fig. $8 \mathrm{~A})$. It is unlikely that this involves the $\Delta \mathrm{Raf}-1: \mathrm{ER}$-induced increase in cyclin E-dependent kinase activity, as similar levels of kinase activity were found in cells expressing dn-p53 or LT (Fig. 6D). In contrast, cyclin Adependent kinase activity was found to be consistently higher in the LT cells (Fig. 8B). Western blot analysis showed that NSARafERLT cells had elevated levels of cyclin A and cdk2 when compared with NSARafER or NS $\Delta$ RafERp53 ${ }^{175}$ cells (Fig. 8B), whereas cyclin E levels were unaffected by LT expression (not shown). Cyclin A and cdk2 levels were unaffected by the removal of mitogens (not shown) or by the activation of Raf (Fig. 7B), demonstrating that the increase in expression levels does not correlate with the proliferative rate of the cells and thus appears to be the direct result of LT expression. These findings are consistent with those reported by Oshima et al. (1993), showing that the expression of LT in primary rat lung epithelial cells resulted in a dramatic increase in the expression of cyclin $\mathrm{A}$ and cdc2 proteins.

To address whether the elevated levels of cyclin A complexes induced by LT may contribute to the ability of Raf to stimulate DNA synthesis in the NS $\triangle$ RafER cells, we infected NS $\Delta$ RafERp53 $3^{175}$ cells with a BabeHygro retroviral vector constructed to encode cyclin A. Consistent with a role of cyclin $\mathrm{A}$ in the increased proliferative response to $\Delta$ Raf-1:ER, polyclonal populations of these cells showed an increased proliferative response to $\Delta$ Raf-1:ER, whereas Babe-Hygro-infected control cells behaved as the parental cells (Fig. 8A, right). These results show that the induction of cyclin A by LT is likely to contribute to the increased proliferation seen in response to Raf, although as LT is a multifunctional protein, other factors are likely to be involved as well.

When we measured cyclin A-dependent kinase activity in NS $\triangle$ RafERLT cells we found that in the complete absence of exogenous mitogens, the complexes were mostly inactive, even though the levels of the complexes were similar to those seen in the presence of mitogens (Fig. $8 \mathrm{C}$ ). Activation of $\Delta$ Raf-1:ER in these conditions stimulated a 3- to 4-fold increase in the proportion of cells in $\mathrm{S}$ phase, as measured by FACS analysis or $\left[{ }^{3} \mathrm{H}\right]$ thymidine uptake (not shown) and resulted in a 8- to 20 -fold increase in kinase activity (Fig. 8C, top). This activation was not associated with a detectable change in the levels of cyclin A/cdk2 complexes (Fig. 8C, bottom) and thus represents an increase in the specific activity of the complexes. Addition of mitogens also increased the cyclin A-dependent kinase activity and subsequent activation of Raf resulted in a further two- to fivefold stimulation of kinase activity (Fig. 8C), although a small increase (less than twofold) in cdk2 levels was seen upon Raf activation under these conditions. Activation of cdk2-dependent kinase activity was stimulated to a similar extent (not shown), indicating the increase in kinase activity was at the level of the cyclin $\mathrm{A} / \mathrm{cdk} 2$ complexes.

Thus Raf signaling and LT function not only converge to regulate cyclin $\mathrm{E} / \mathrm{cdk} 2$ activity but also cooperate to increase cyclin $\mathrm{A} / \mathrm{cdk} 2$ activity with LT-inducing cyclin $\mathrm{A} / \mathrm{cdk} 2$ levels and Raf increasing the specific activity of these complexes. This effect is most apparent in the absence of exogenous mitogens, suggesting that Raf and mitogens may activate the complexes by a similar mechanism. Thus cooperation between Raf and LT involves both the loss of a cell cycle inhibitor protein and the synergistic activation of cyclin A complexes.

\section{Discussion \\ Cooperating oncogenes target cyclin/cdk inhibitors}

We have shown that cooperating oncogenes can regulate cyclin/cdk complexes by distinct inhibitory and activating mechanisms. Such regulation appears to play a key role in determining the specificity of the cellular response to the Ras/Raf pathway. Activation of an inducible Raf protein alone results in a $\mathrm{G}_{1}$-specific cell cyle arrest mediated by an induction of $\mathrm{p} 21^{\mathrm{Cip} 1}$ and the concomitant inhibition of cyclin/cdk activity. In the presence of LT or dominant-negative mutants of p53, however, the $\mathrm{p} 21^{\mathrm{Cip} 1}$ induction is suppressed, the ability of Raf to increase the specific activity of cyclin-dependent kinases is revealed, and the growth arrest abolished (Fig. 9). This effect is most evident in cells containing LT, as they express higher levels of cyclin $\mathrm{A} / \mathrm{cdk} 2$ complexes and in these cells Raf activation is sufficient to stimulate proliferation in the absence of exogenous growth factors.

Our experiments support the idea that the $\mathrm{p} 21^{\mathrm{Cip} 1}$ induction is at least in part responsible for the Raf-dependent cell cycle arrest. As such, its suppression by cooperating oncogenes plays an essential role in cellular transformation. Indeed, it appears that the suppression of cdk inhibitor proteins is a common property of immortalizing oncogenes that cooperate with Ras and/or Raf. E1A is able to bind to and block the inhibitory effects of 


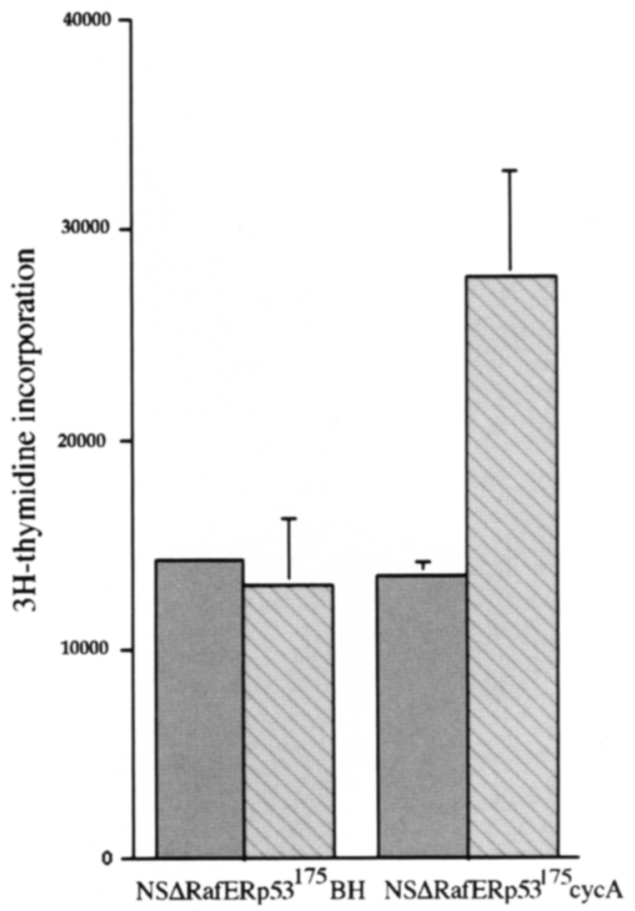

Figure 8. Raf and LT cooperate to induce high levels of cyclin Adependent kinase activity and DNA synthesis. $(A$, left $)$ Equal numbers of NS $\triangle$ RafERBp, NSARafERp53 ${ }^{175}$, NS $\triangle$ RafERLT cells were seeded into DMEM supplemented with $2 \%$ FCS. Forty-eight hours later the cells were stimulated with fresh medium supplemented with $3 \%$ FCS, forskolin, and GGF in the presence of TMX $|+|$ or the control solvent $(-) .\left[{ }^{3} \mathrm{H}\right]$ Thymidine was added $12 \mathrm{hr}$ later and the cells were harvested after a further $18 \mathrm{hr}$. TCA precipitable material was filtered and counted. (Right) NS $\Delta$ RafERp53 $3^{175}$ cells were infected with the Babe hygro retroviral vector constructed to express the cyclin A gene or the empty vector control to generate NS $\Delta$ RafERp $53^{175} \mathrm{cycA}$ and NS $\triangle$ RafERp $53^{175} \mathrm{BH}$ cells, respectively. Hygromycin-resistant colonies were pooled and expanded. DNA synthesis assays were performed as described above. $(B)$ Protein lysates were prepared from growing NSARafER, NS $\Delta$ RafERp53 $53^{175}$ and

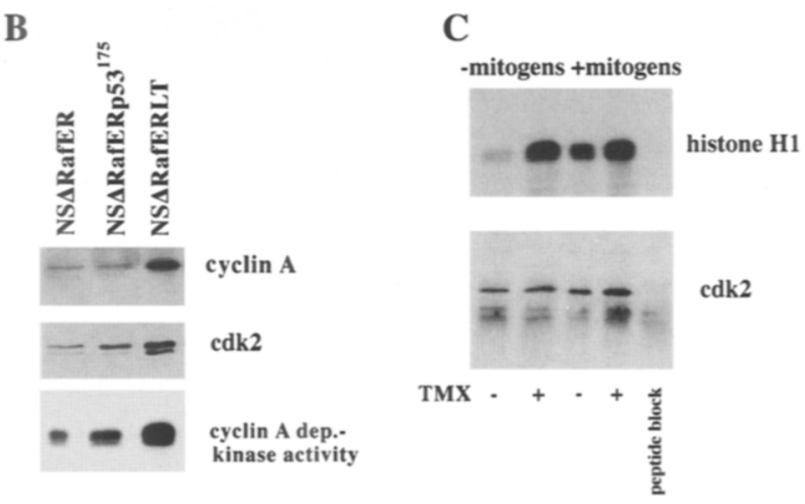
NS $\triangle$ RafERLT cells. Thirty micrograms of protein was analyzed by Western blotting with either an anti-cyclin A or anti-cdk2 antibody as indicated (top and middle panels). One hundred micrograms of the lysates was immunoprecipitated with an anti-cyclin A antibody and assayed for histone H1 kinase activity (bottom). (C) NSARafERLT cells were seeded into DMEM supplemented with SATO mix, a serum-free medium supplement (Brockes et al. 1979), (-mitogens) or DMEM supplemented with $3 \%$ FCS, GGF, and forskolin $\{+$ mitogens) for $48 \mathrm{hr}$ prior to the experiment. The cells were then treated with TMX $(+)$ or control solvent $(-)$ for $24 \mathrm{hr}$ and protein lysates were prepared. Two hundred micrograms of protein was immunoprecipitated with an anti-cyclin A antibody and kinase assays were performed with the precipitates. The kinase reactions were subjected to SDS-PAGE and then transferred onto a PVDF membrane. The filter was exposed to film (top) and then Western blotted with an anti-cdk2 antibody (bottom).

p27 $7^{\text {Kip1 }}$ (Mai et al. 1996) and p16 ${ }^{\text {INK4A }}$ (Serrano et al. 1995). Similarly, Myc can overcome cell cycle inhibiton by $27^{\text {Kip } 1}$ (Vlach et al. 1996; I. Perez-Roger, D.L.C. Solomon, and H. Land, in prep.), p21 ${ }^{\mathrm{Cip} 1}$ (A. Sewing and H. Land, in prep.), and $\mathrm{pl} 6^{\mathrm{INK} 4 \mathrm{~A}}$ (B. Amati, pers. comm.; $\mathrm{S}$. Shellard and $\mathrm{H}$. Land, unpubl.) in fibroblasts via yet unknown mechanisms. In addition, fibroblasts isolated from mice carrying a targeted deletion of the INK4a tumor suppressor locus, which encodes the cdk4/cdk6 inhibitory protein $\mathrm{p} 16^{\mathrm{INK} 4 \mathrm{~A}}$, can be transformed by Ras or Raf alone (Serrano et al. 1996). This suggests that, similarly to Raf in Schwann cells, a reduction in the level of cyclin/cdk inhibitory proteins reveals the transforming potential of Ras in fibroblasts.

\section{DNA damage-independent role of p53}

The activity of p53 is pivotal to the switch in Raf from a growth-inhibitory to a stimulatory signal. Previous work has demonstrated a critical role of p53 in $\mathrm{G}_{1}$ arrest and apoptosis induced by DNA damage after UV irradiation (Kastan et al. 1992; Kuerbitz et al. 1992). Here we show that the activation of the Raf pathway arrests Schwann cells in a p53-dependent fashion in the absence of DNA damage. Thus, it is tempting to speculate that the ability of p53 to modulate the proliferative response to signals such as Ras/Raf activation may play an important role in its function as a tumor suppressor gene. It is possible that the constitutive activation of the Raf pathway may 


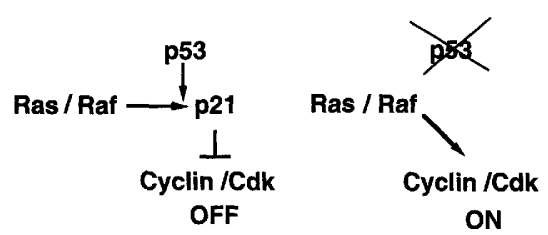

Figure 9. Signaling by cooperating oncogenes converges at the regulation of cyclin/cdk complexes. In Schwann cells Ras or Raf oncogenes induce a $G_{1}$-specific cell cycle arrest via induction of $\mathrm{p} 21^{\mathrm{Cip} 1}$ and the concomitant inhibition of cyclin/cdk activity. In the absence of functional $\mathrm{p} 53$, however, the $\mathrm{p} 21^{\mathrm{Cip} 1}$ induction is suppressed and the growth arrest abolished. In the absence of $\mathrm{p} 21^{\mathrm{Cip} 1}$ the ability of Raf to activate cyclin/cdk activity is revealed. Thus Raf elicits either growth inhibitory or stimulatory signals depending on the presence of functional p53.

mimic a damage signal and therefore be sensed by $\mathrm{p} 53$ as inappropriate. However, the expression of dn-p53 mutants reduces the growth factor requirement of Schwann cells in the absence of activated Raf (Fig. 7A; data not shown), which suggests a function for $\mathrm{p} 53$ in the regulation of normal proliferative signals.

\section{Raf induces $p 21^{\text {Cip } 1}$ by a p53-dependent mechanism}

The $\Delta$ Raf-induced $G_{1}$ arrest is preceded by a loss of cyclin $\mathrm{E}$ - and cyclin A-dependent kinase activity. The inhibition of cyclin A-dependent kinase activity appears to result from a corresponding decrease in the levels of cyclin $\mathrm{A} / \mathrm{cdk} 2$ complexes, reflecting a block prior to the induction of cyclin A expression. In contrast, the suppression of cyclin E-dependent kinase is attributable to an inhibition of the specific activity of cyclin $\mathrm{E} / \mathrm{cdk} 2$ complexes that is likely to be a result of increased expression and binding of the inhibitor protein $\mathrm{p} 21^{\mathrm{Cip} 1}$ to the complex. The arrested state induced by Raf is very different from the quiescent state resulting from the removal of growth factors in terms of the balance of cyclin/cdk complexes and inhibitor levels. In addition to elevated $\mathrm{p} 21^{\text {Cip } 1}$ expression, Raf-arrested cells also overexpress cyclin D1, whereas $\mathrm{p} 21^{\mathrm{Cip} 1}$ and cyclin $\mathrm{D} 1$ are barely detectable in quiescent cells. Moreover, in quiescent cells the amount of cdk 2 bound to cyclin E is very low, whereas the levels of cyclin $\mathrm{E} / \mathrm{cdk} 2$ complexes in Raf-arrested cells are similar to those in proliferating cells (A. Lloyd and $\mathrm{H}$. Land, unpubl.).

It has been shown previously that overexpression of p21 $1^{\text {Cip1 }}$ leads to a cell cycle arrest in $G_{1}$ (Harper et al. 1995). Moreover, p53-dependent $G_{1}$ arrest in response to DNA damage is largely dependent on $\mathrm{p} 21^{\mathrm{Cip} 1}$ (Brugarolas et al. 1995; Deng et al. 1995; Waldman et al. 1995). Our observation that $\gamma$-irradiation or Raf activation involve equivalent levels of $\mathrm{p} 21^{\mathrm{Cip} 1}$ in Schwann cells (Fig. 7A) is thus consistent with our view that $\mathrm{p} 21^{\mathrm{Cip} 1}$ is causally involved in the Raf-induced growth arrest.

Similar to the experiments shown here, others have investigated cyclin/cdk activity following various stimuli that lead to a $G_{1}$ arrest associated with the induction of cdk inhibitory proteins. p53-dependent $G_{1}$ ar- rest in response to DNA damage (Dulic et al. 1994), which is known to be significantly dependent on p $21^{\mathrm{Cip} 1}$, or the induction of the $\mathrm{G}_{1}$ inhibitory proteins $\mathrm{p} 21^{\mathrm{Cip} 1}$ and $\mathrm{p} 27^{\mathrm{Kip} 1}$ following the detachment of cells from the substratum (Fang et al. 1996) each results in a $G_{1}$ arrest associated with a decrease in both cyclin $E$ and cyclin A-dependent kinase activity. Interestingly, in both cases as well as in our system, this involves an inhibition of the specific activity of cyclin E kinases, resulting in a block in $G_{1}$ prior to the induction of cyclin A. Thus, cyclin $E / c d k 2$ complexes appear to be a target for $\mathrm{p} 21^{\mathrm{Cip} 1}$ and $\mathrm{p} 27^{\mathrm{Kipl} 1}$ when induced by various mechanisms. This is consistent with cyclin E/cdk2 activity being required for the induction of cyclin A expression (Rudolph et al. 1996). It is possible that $\mathrm{p} 21^{\mathrm{Cip} 1}$ is also inhibiting cyclin D-dependent kinase activity, although because of the technical difficulties in measuring cyclin D-dependent kinase activity in these cells, this was not further investigated.

The regulation of $\mathrm{p} 21^{\mathrm{Cip} 1}$ expression appears complex. DNA damage signals are known to result in the induction of $\mathrm{p} 21^{\mathrm{Cip} 1}$ in a p53-dependent fashion via two conserved p53-binding sites in the promoter (Dulic et al. 1994; Michieli et al. 1994; Macleod et al. 1995). The $\mathrm{G}_{1}$ arrest associated with these signals has been shown to be partly or fully dependent upon $\mathrm{p} 21^{\text {Cip1 }}$ (Brugarolas et al. 1995; Deng et al. 1995; Waldman et al. 1995). However, p $21^{\text {Cipl }}$ expression is induced as an immediate early gene, by various mitogens and differentiation agents and by the growth inhibitory peptide transforming growth factor- $\beta$ (TGF- $\beta$ ), in a p53-independent fashion (Jiang et al. 1994; Li et al. 1994; Michieli et al. 1994; Steinman et al. 1994) and the response to mitogens can be blocked or mimicked by inhibitors or activators of the MAP kinase pathway (Liu et al. 1996). The role of the induction of p2 $1^{\text {Cip } 1}$ as cells enter the cycle is unclear, although it has been proposed that $\mathrm{p} 21^{\mathrm{Cip} 1}$ may act as an assembly factor of cyclin/cdk complexes (Zhang et al. 1994). Elevated levels of $\mathrm{p} 21^{\text {Cipl }}$ expression are also associated with the differentiated state of specific tissues and have been postulated to be involved in the maintenance of the quiescent differentiated state (Halevy et al. 1995; Macleod et al. 1995). The latter has also been shown to be a p53independent mechanism. In Schwann cells, we show that the Raf-dependent induction of $\mathrm{p} 21^{\mathrm{Cip} 1}$ is a $\mathrm{p} 53$ dependent process and thus differs from the immediate early response seen following mitogen stimulation. It will be of interest to dissect the mechanisms involved in this p53-dependent induction.

In contrast to the rapid induction of cyclin $\mathrm{D} 1$ in response to Raf activation, the induction of $\mathrm{p}^{2} 1^{\mathrm{Cipl}}$ is delayed. This suggests that the mechanism by which Raf stimulates $\mathrm{p} 21^{\mathrm{Cip} 1}$ expression may be indirect. The kinetics of the induction, however, may explain how activation of the same pathway, that is, the MAP-kinase pathway, can result in opposing effects on the cell cycle. If constitutive activation of the MAP kinase pathway for several hours is required to induce $\mathrm{p} 21^{\mathrm{Cip} 1}$, this may partly explain why transient activation of the same pathway by mitogens stimulates rather than inhibits the cell cycle. 


\section{Raf activates cyclin/cdk activity in presence of a cooperating partner}

In the absence of normal p53 function, Raf activation results in an increase in cyclin/cdk activity, presumably by a mechanism that can be suppressed by $\mathrm{p} 21^{\mathrm{Cip} 1}$. This demonstrates that the effects of an oncogene cannot be gauged solely by the introduction of a single oncogene into a primary cell, as the specificity of the cellular response can depend on the expression of other cooperating genes. In addition to inhibiting p53, LT leads to the constitutive overexpression of cyclin $\mathrm{A} / \mathrm{cdk} 2$ complexes with Raf activation causing a superinduction of the kinase activity. In this context it is noteworthy that although loss of functional p53 abolishes the Raf-induced cell cycle arrest, only cells expressing LT respond to Raf activation with increased proliferation. The elevation of the cyclin A complexes appears to be at least partly responsible for the ability of Raf to stimulate proliferation in these cells, as p53-defective cells infected with a cyclin A-carrying retrovirus are similarly induced to cycle by Raf. Preliminary experiments indicate that the mechanism of this activation does not involve further alterations in the levels of $\mathrm{p} 21^{\mathrm{Cip} 1}$ or $\mathrm{p} 27^{\mathrm{kip}-1}$ or $\mathrm{cdc} 25$ dependent dephosphorylation of $\operatorname{cdk} 2$ /A. Lloyd and $\mathrm{H}$. Land, unpubl.). As the activation of cyclin-dependent kinase activity appears to be induced in a similar fashion by growth factors (Fig. $8 \mathrm{C}$ ) it will be important to identify the mechanisms involved in this process.

\section{Implications for neurofibromatosis}

The model system that we have developed demonstrates how progressive genetic changes contribute to the transformed phenotype and describe some of the molecular mechanisms involved. Raf alone leads to a change in the morphology of the cells, coincident with an increase in cell motility and the induction of growth factor secretion, all of which can be imagined to disrupt the microenvironment of the cell. However, these cells are growth-arrested as a result of the induction of $\mathrm{p}^{1} \mathrm{l}^{\mathrm{Cip} 1}$. Inactivation of p53 abolishes the growth arrest, while retaining the other Raf-dependent properties. The coexpression of LT, in addition, results in the cooperative activation of cyclin A-dependent kinases, and these cells acquire the ability to proliferate in response to the Raf signal in the absence of exogenous mitogens.

In neurofibromatosis type 1 , the Ras pathway is activated via inactivation of neurofibromin, a Ras-GAP (Ballester et al. 1990; Martin et al. 1990; Xu et al. $1990 a, b)$. Inhibition of the Ras pathway in tumor cells derived from these patients results in a reversion of the tumor cells, confirming the role of Ras in tumor formation in this disease (Basu et al. 1992; DeClue et al. 1992). We have shown that activation of Raf in primary Schwann cells, as reported previously for Ras (Ridley et al. 1988/, results in a growth arrest of the cells. In addition, a recent report described the isolation of Schwann cells from NF-/- embryos. These Schwann cells were shown to have elevated levels of Ras-GTP, resembled
Ras-infected Schwann cells, and grew much more slowly than the wild-type cells (Kim et al. 1995), demonstrating that the observable NF-/ - phenotype is mimicked by activation of the Ras/Raf pathway. The poor growth properties of primary Schwann cells in which the Ras pathway is activated suggest that further genetic events are required for tumor formation in this cell type. It will be of great interest to investigate whether the benign and malignant tumors found in patients suffering from neurofibromatosis type $I$ have further genetic defects that result in the suppression of the effects of $\mathrm{p} 21^{\mathrm{Cip} 1}$. These may involve the loss of $\mathrm{p} 21^{\text {Cip } 1}$ or $\mathrm{p} 53$ expression, mutations that affect cyclin $/ \mathrm{p} 21^{\mathrm{Cip} 1}$ interaction, or increases in the levels of cyclin/cdk complexes. Interestingly, reports of p53 mutations in neurofibrosarcomas from neurofibromatosis type 1 patients have been reported previously (Menon et al. 1990).

\section{Oncogene cooperation in cell regulation}

Cooperating oncogenic lesions are expected to increase the proliferative advantage of tumor cells. However, it is remarkable that as part of this process they enhance the oncogenic potential of each other. This applies not only to the cooperation between Raf and LT or loss of p53 function, but also to the cooperation between Myc and Bcl-2 where the latter blocks Myc-induced apoptosis and reveals the ability of Myc to induce cell cycle entry (Fanidi et al. 1992). The Ras/Raf pathway is involved in many cellular responses to peripheral signals and in the experimental system used here activates two mutually exclusive cellular programs: cell cycle progression and cell cycle arrest. The decision of whether to progress through the cell cycle or to arrest, however, is determined by multiple signals converging at the regulation of cyclin/cdk complexes. How cellular signaling networks specify cellular decisions is of central importance to the understanding of cell regulation. Models in which the cooperation of oncogenes or other signaling molecules can be studied at the molecular level will provide a powerful tool to explore this question.

\section{Materials and methods}

\section{Cell culture}

Schwann cells were purified from 2- to 3-day old Wistar rats, as described previously (Brockes et al. 1979; Ridley et al. 1988). The Schwann cells were cultured routinely at $37^{\circ} \mathrm{C}\left(10 \% \mathrm{CO}_{2}\right)$ in DMEM with $1.5 \mathrm{mg} / \mathrm{ml}$ glucose, supplemented with $3 \%$ FCS, $1 \mu \mathrm{M}$ forskolin (Calbiochem) and GGF (a kind gift from Mark Noble, University of Utah, Salt Lake City), on dishes precoated with poly-L-lysine (Sigma). Throughout all the experiments phenol red-minus medium and charcoal-stripped serum were used. To render the cells quiescent, the cells were washed twice in DMEM and incubated in either DMEM supplemented with $2 \%$ FCS or B/S medium, a mitogen-free supplement (Raff et al. 1983), for $48 \mathrm{hr}$.

\section{Retroviral vectors}

The XhoI-ClaI(blunted) fragment encoding $\Delta$ Raf-1:ER (Samuels et al. 1993) was subcloned into the XhoI-BamHI(blunted) site of 
the retroviral vector (Miller and Rosman 1989). The BamHI fragment encoding SV40LT (Jat et al. 1986) and a BamHI fragment encoding human $\mathrm{p} 53^{175}$ (provided by David Lane) (Voitesek et al. 1992) were subcloned into the BamHI site of the BabePuro retroviral (Morgenstern and Land 1990). A sequenced PCR fragment encoding amino acids 302-390 of murine p53 (p53 ${ }^{\mathrm{CT}}$ ) was subcloned into the BamHI-EcoRI site of Babe-Puro (a kind gift of Trevor Littlewood, ICRF, London, UK). A BamHI-SalI fragment encoding the human cyclin A gene la kind gift from Jonathan Pines, Wellcome/CRC Institute, Cambridge, UK) was subcloned into the BamHI-Sall sites of the Babe-Hygro retroviral vector (Morgenstern and Land 1990). A XhoI-BglII fragment encoding rat p21 cDNA (R. Mazars and P. Jat, unpubl.) was subcloned into the XhoI-BamHI sites of the pBabe-Puro/ 2 vector. Each of the constructs was transfected, using the standard calcium phosphate method, into the packaging cell line GP+E (Markowitz et al. 1990), and G418, hygromycin, or puromycin colonies were pooled and expanded.

\section{Infection of Schwann cells}

Schwann cells were infected by cocultivation, at a 1:2 ratio, with the producer cell lines, which had been pretreated for $2 \mathrm{hr}$ with $20 \mu \mathrm{g} / \mathrm{ml}$ of mitomycin C (Sigma). Two to three days after plating the cultures were transferred into selective medium containing $400 \mu \mathrm{g} / \mathrm{ml} \mathrm{G} 418$ (GIBCO) or $0.4 \mu \mathrm{g} / \mathrm{ml}$ puromycin (Sigma) as appropriate. Drug-resistant colonies were pooled and expanded.

\section{FACS analysis and DNA synthesis assays}

Cells $\left(1 \times 10^{6}\right.$ to $\left.2 \times 10^{6}\right)$ were preincubated for $4 \mathrm{hr}$ with $10 \mu \mathrm{M}$ BrdU(Sigma), trypsinized and then fixed in $80 \%$ ethanol. The fixed cells were then incubated with fluorescein isothiocyanatecojugated anti-BrdU antibodies (Becton-Dickinson) and stained with propidium iodide containing RNase $(20 \mu \mathrm{g} / \mathrm{ml})$. Replicative DNA synthesis and DNA content were analyzed using bivariate flow cytometry. For DNA synthesis assays, $5 \times 10^{4}$ cells were seeded in triplicate into six-well dishes in conditions as described in the figure legends. $\left[{ }^{3} \mathrm{H}\right]$ thymidine was used at a concentration of $0.5 \mu \mathrm{Ci} / \mathrm{ml}$. At the indicated times the cells were lysed in $1 \%$ SDS and the trichloroacetic acid (TCA)-precipitable material was filtered and counted.

\section{Western blot analysis}

The cells were lysed in buffer A $11 \%$ NP-40, $50 \mathrm{~mm}$ Tris at $\mathrm{pH}$ $8,150 \mathrm{mM} \mathrm{NaCl} 10 \mu \mathrm{g} / \mathrm{ml}$ of aprotinin, leupeptin, and pepstatin, $20 \mathrm{~mm} \mathrm{NaF}, 1 \mathrm{~mm} \mathrm{Na} \mathrm{VO}_{4} 100 \mu \mathrm{g} / \mathrm{ml}$ of PMSF). Protein concentration was determined using the Biorad protein assay. Thirty micrograms of lysate were resolved by SDS-PAGE and electroblotted onto Immobilon P membranes (Millipore). The following antibodies were used: anti-p42 ERK-2 $\{122\}$, provided by Chris Marshall (Leevers and Marshall 1992); anti-cyclin D1, provided by Gordon Peters (Bates et al. 1994); anti-cyclin E (Santa Cruz, sc-481); anti-cyclin A-E-23, provided by Julian Gannon and Tim Hunt (ICRF, South Mimms, UK); anti-cdk4 (Santa Cruz, sc-749); anti-cdk2 (Santa Cruz, sc-163); anti-p27 (Santa Cruz, sc-528); anti-p21(CP36), provided by Wade Harper (Baylor College of Medicine, Houston, TX), anti-hER (Samuels et al. 1993), and anti-p53 (Santa Cruz, sc-1313). Immunoreactive bands were visualized using enhanced chemiluminescence detection (Amersham International PLC).

\section{Immunoprecipitations and kinase assays}

Cells were lysed in buffer A. Three hundred micrograms of lysate was incubated with $10 \mu \mathrm{g}$ of antibody [cyclin E-Santa Cruz 481, cyclin A-E72, provided by Julian Gannon and Tim Hunt (Slingerland et al. 1994), cdk-2-Santa Cruz 163] for $1 \mathrm{hr}$ at $37^{\circ} \mathrm{C}$, followed by incubation for an additional hour with protein $\mathrm{A}$ - or protein G-sepharose, as appropriate. The beads were washed five times in buffer $\mathrm{A}$ and subjected either to Western blot analysis or to kinase assays. For kinase assays the beads were washed a further two times in kinase buffer $150 \mathrm{~mm}$ Tris at $\mathrm{pH}$ $7.5,10 \mathrm{mM} \mathrm{MgCl}_{2}, 1 \mathrm{~mm}$ dithiothreitol) and then resuspended in $50 \mu \mathrm{l}$ of kinase buffer supplemented with $50 \mu \mathrm{M}$ ATP, $5 \mu \mathrm{Ci}$ $\left.{ }^{32} \mathrm{P}\right] \mathrm{ATP}$ and $10 \mu \mathrm{g}$ of histone $\mathrm{H1}$ (Boehringer Mannheim) for 30 min at $37^{\circ} \mathrm{C}$. The samples were resolved by SDS-PAGE and exposed to Kodak X-OMAT AR. The kinase assays were quantified using ImageQuant by Molecular Dynamics.

\section{Acknowledgments}

We thank Chris Gilbert for the time-lapse cinematography, Derek Davies and Clare Hughes for FACS analysis, and Raoul Mazars and Parmjit Jat for the kind gift of rat p21 cDNA. We also thank Gordon Peters, Nic Jones, David Mann, and Emma Lees for critical reading of the manuscript and Chris Marshall and Mark Burfoot for helpful discussions. This work was sponsored by a grant from the Department of the U.S. Army DAMD17-93-J-3033. A.L. was partially supported by the Jaffa fellowship awarded by the National Neurofibromatosis Foundation, New York, NY. The DNAX Research Institute is supported by Schering Plough Corporation.

The publication costs of this article were defrayed in part by payment of page charges. This article must therefore be hereby marked "advertisement" in accordance with 18 USC section 1734 solely to indicate this fact.

\section{References}

Ballester, R., D. Marchuk, M. Boguski, A. Saulino, R. Letcher, M. Wigler, and F. Collins. 1990. The NF1 locus encodes a protein functionally related to mammalian GAP and yeast IRA proteins. Cell 63: 851-859.

Basu, T.N., D.H. Gutmann, J.A. Fletcher, T.W. Glover, F.S. Collins, and J. Downward. 1992. Aberrant regulation of ras proteins in malignant tumour cells from type 1 neurofibromatosis patients. Nature 356: 713-715.

Bates, S., D. Parry, L. Bonetta, K. Vousden, C. Dickson, and G. Peters. 1994. Absence of cyclin D/cdk complexes in cells lacking functional retinoblastoma protein. Oncogene 9: 1633-1640.

Brockes, J.P., K.L. Fields, and M.C. Raff. 1979. Studies on cultured rat Schwann cells. I. Establishment of purified populations from cultures of peripheral nerve. Brain Res. 165: 105-118.

Brugarolas, J., C. Chandrasekaran, J.I. Gordon, D. Beach, T. Jacks, and G.J. Hannon. 1995. Radiation-induced cell cycle arrest compromised by p21 deficiency. Nature 377: 552-557.

DeClue, J.E., A.G. Papageorge, J.A. Fletcher, S.R. Diehl, N. Ratner, W.C. Vass, and D.R. Lowy. 1992. Abnormal regulation of mammalian p21ras contributes to malignant tumor growth in von Recklinghausen (type 1) neurofibromatosis. Cell 69: 265-273.

Deng, C., P. Zhang, J.W. Harper, S.J. Elledge, and P. Leder. 1995. Mice lacking $221^{\mathrm{Cip} 1 / \mathrm{WAF} 1}$ undergo normal development, but are defective in G1 checkpoint control. Cell 82: 675-684.

Dulic, V., W.K. Kaufmann, S.J. Wilson, T.D. Tlsty, E. Lees, J.W. Harper, S.J. Elledge, and S.I. Reed. 1994. p53-dependent in- 
hibition of cyclin-dependent kinase activities in human fibroblasts during radiation-induced G1 arrest. Cell 76: 10131023.

el-Deiry, W., T. Tokino, V.E. Velculescu, D.B. Levy, R. Parsons, J.M. Trent, D. Lin, W.E. Mercer, K.W. Kinzler, and B. Vogelstein. 1993. WAF1, a potential mediator of p53 tumor suppression. Cell 75: 817-825.

Fang, F., G. Orend, N. Watanabe, T. Hunter, and E. Ruoslahti. 1996. Dependence of cyclin E-CDK2 kinase activity on cell anchorage. Science 271: 499-502.

Fanidi, A., E.A. Harrington, and G.I. Evan. 1992. Cooperative interaction between c-myc and bcl-2 proto-oncogenes. $\mathrm{Na}$ ture 359: 554-556.

Finlay, C.A., P.W. Hinds, T.H. Tan, D. Eliyahu, M. Oren, and A.J. Levine. 1988. Activating mutations for transformation by 553 produce a gene product that forms an hsc 70-p 53 complex with an altered half-life. Mol. Cell. Biol. 8: 531-539.

Girard, F., U. Strausfeld, A. Fernandez, and N.J. Lamb. 1991. Cyclin $A$ is required for the onset of DNA replication in mammalian fibroblasts. Cell 67: 1169-1179.

Gonos, E.S., J.S. Burna, G.R. Mazars, A. Kobrna, T.E. Riley, S.C. Barnett, G. Zafarana, R.L. Ludwig, Z. Ikram, A.J. Powell, and P.S. Jat. 1996. Rat embryo fibroblasts immortalised with simian virus large $\mathrm{T}$ antigen undergo senescence upon its inactivation. Mol. Cell. Biol. 16: 5127-5138.

Gu, Y., J. Rosenblatt, and D.O. Morgan. 1992. Cell cycle regulation of CDK2 activity by phosphorylation of Thr160 and Tyr15. EMBO I. 11: 3995-4005.

Halevy, O., B.G. Novitch, D.B. Spicer, S.X. Skapek, J. Rhee, G.J. Hannon, D. Beach, and A.B. Lassar. 1995. Correlation of terminal cell cycle arrest of skeletal muscle with induction of p21 by MyoD. Science 267: 1018-1021.

Harper, J.W., G.R. Adami, N. Wei, K. Keyomarsi, and S.J. Elledge. 1993. The p21 Cdk-interacting protein Cipl is a potent inhibitor of $\mathrm{Gl}$ cyclin-dependent kinases. Cell 75: 805-816.

Harper, J.W., S.J. Elledge, K. Keyomarsi, B. Dynlacht, L.H. Tsai, P. Zhang, S. Dobrowolski, C. Bai, C.L. Connell, E. Swindell, et al. 1995. Inhibition of cyclin-dependent kinases by $\mathrm{p} 21$. Mol. Biol. Cell 6: 387-400.

Harvey, D.W. and A.J. Levine. 1991. p53 alteration is a common event in the spontaneous immortalization of primary BALB/c murine embryo fibroblasts. Genes \& Dev. 5: 23752385.

Hunter, T. 1991. Cooperation between oncogenes. Cell 64: 249270.

Jat, P.S., C.L. Cepko, R.C. Mulligan, and P.A. Sharp. 1986. Recombinant retroviruses encoding simian virus 40 large $T$ antigen and polyomavirus large and middle $\mathrm{T}$ antigens. Mol. Cell. Biol. 6: 1204-1217.

Jiang, H., J. Lin, Z.Z. Su, F.R. Collart, E. Huberman, and P.B. Fisher. 1994. Induction of differentiation in human promyelocytic HL-60 leukemia cells activates p21, WAF1/CIP1, expression in the absence of p53. Oncogene 9: 3397-3406.

Kastan, M.B., Q. Zhan, W.S. el-Deiry, F. Carrier, T. Jacks, W.V. Walsh, B.S. Plunkett, B. Vogelstein, and A.J. Fornace. 1992. A mammalian cell cycle checkpoint pathway utilizing p53 and GADD45 is defective in ataxia-telangiectasia. Cell 71: 587597.

Kern, S.E., J.A. Pietenpol, S. Thiagalingam, A. Seymour, K.W. Kinzler, and B. Vogelstein. 1992. Oncogenic forms of p53 inhibit p53-regulated gene expression. Science 256: 827-830.

Kim, H.A., T. Rosenbaum, M.A. Marchionni, N. Ratner, and J.E. DeClue. 1995. Schwann cells from neurofibromin deficient mice exhibit activation of p21ras, inhibition of cell proliferation and morphological changes. Oncogene 11: 325-335.
Kuerbitz, S.J., B.S. Plunkett, V.W. Walsh, and M.B. Kastan. 1992. Wild-type p53 is a cell cycle checkpoint determinant following irradiation. Proc. Nat1. Acad. Sci. 89: 7491-7495.

Lane, D.P. and L.V. Crawford. 1980. The complex between simian virus $40 \mathrm{~T}$ antigen and a specific host protein. Proc. $R$. Soc. Lond. B. Biol. Sci. 210: 451-463.

Leevers, S.J. and C.J. Marshall. 1992. Activation of extracellular signal-regulated kinase, ERK2, by p21ras oncoprotein. EMBO T. 11: 569-574.

Li, Y., C.W. Jenkins, M.A. Nichols, and Y. Xiong. 1994. Cell cycle expression and 553 regulation of the cyclin-dependent kinase inhibitor p21. Oncogene 9: 2261-2268.

Liu, J.J., J.R. Chao, M.C. Jiang, S.Y. Ng, J.J. Yen, and Y.H. Yang. 1995. Ras transformation results in an elevated level of cyclin D1 and acceleration of G1 progression in NIH 3T3 cells. Mol. Cell. Biol. 15: 3654-3663.

Liu, Y., J.L. Martindale, M. Gorospe, and N.J. Holbrook. 1996. Regulation of $\mathrm{p} 21^{\mathrm{WAF} 1-\mathrm{CIP} 1}$ expression through mitogen-activated protein kinase signaling pathway. Cancer Res. 56: 31-35.

Lukas, J., H. Muller, J. Bartkova, D. Spitkovsky, A.A. Kjerulff, D.P. Jansen, M. Strauss, and J. Bartek. 1994. DNA tumor virus oncoproteins and retinoblastoma gene mutations share the ability to relieve the cell's requirement for cyclin D1 function in G1. I. Cell Biol. 125: 625-638.

Macleod, K.F., N. Sherry, G. Hannon, D. Beach, T. Tokino, K. Kinzler, B. Vogelstein, and T. Jacks. 1995. p53-dependent and independent expression of p21 during cell growth, differentiation, and DNA damage. Genes \& Dev. 9: 935-944.

Mai, A., R.Y.C. Poon, P.H. Howe, H. Toyoshima, T. Hunter, and M.L. Harter. 1996. Inactivation of $\mathrm{p} 27^{\mathrm{Kipl} 1}$ by the viral E1A oncoprotein in TGF $\beta$-treated cells. Nature 380: 262-265.

Maltzman, W., M. Oren, and A.J. Levine. 1981. The structural relationships between 54,000-molecular-weight cellular tumor antigens detected in viral- and nonviral-transformed cells. Virology 112: 145-156.

Markowitz, D., C. Hesdorffer, M. Ward, S. Goff, and A. Bank. 1990. Retroviral gene transfer using safe and efficient packaging cell lines. Ann. N.Y. Acad. Sci. 612: 407-414.

Martin, G.A., D. Viskochil, G. Bollag, P.C. McCabe, W.J. Crosier, H. Haubruck, L. Conroy, R. Clark, P. O'Connell, R.M. Cawthon, et al. 1990. The GAP-related domain of the neurofibromatosis type 1 gene product interacts with ras $\mathrm{p} 21$. Cell 63: 843-849.

Matsushime, H., D.E. Quelle, S.A. Shurtleff, M. Shibuya, C.J. Sherr, and J.Y. Kato. 1994. D-type cyclin-dependent kinase activity in mammalian cells. Mol. Cell. Biol. 14: 2066-2076.

Mazarakis, N.D., N. Yannoutsos, J.N. El-Jabbour, W. Hatton, R. Fletcher, and F. Grosveld. 1996. Neurocristopathy resembling neurofibromatosis type 1 in an NGF-SV40 transgenic line. Genes Cells 1: 125-137.

Menon, A.G., K.A. Anderson, V.M. Riccardi, R.Y. Chung, J.M. Whaley, D.W. Yandell, G.E. Farmer, R.N. Freiman, J.K. Lee, F.P. Li, et al. 1990. Chromosome 17p deletions and p53 gene mutations associated with the formation of malignant neurofibrosarcomas in von Recklinghausen neurofibromatosis. Proc. Natl. Acad. Sci. 87: 5435-5439.

Michieli, P., M. Chedid, D. Lin, J.H. Pierce, W.E. Mercer, and D. Givol. 1994. Induction of WAF1/CIP1 by a p53-independent pathway. Cancer Res. 54: 3391-3395.

Miller, A.D. and G.J. Rosman. 1989. Improved retroviral vectors for gene transfer and expression. BioTechniques 7: 980-982.

Moodie, S.A., B.M. Willumsen, M.J. Weber, and A. Wolfman. 1993. Complexes of Ras.GTP with Raf-1 and mitogen-activated protein kinase kinase. Science 260: 1658-1661.

Morgenstern, J.P. and H. Land. 1990. Advanced mammalian 
gene transfer: High titre retroviral vectors with multiple drug selection markers and a complementary helper-free packaging cell line. Nucleic Acids Res. 18: 3587-3596.

Noda, A., Y. Ning, S.F. Venable, S.O. Pereira, and J.R. Smith. 1994. Cloning of senescent cell-derived inhibitors of DNA synthesis using an expression screen. Exp. Cell Res. 211: 9098.

Ohtsubo, M., A.M. Theodoras, J. Schumacher, J.M. Roberts, and M. Pagano. 1995. Human cyclin E, a nuclear protein essential for the G1-to-S phase transition. Mol. Cell. Biol. 15: 2612-2624.

Oshima, J., K.E. Steinmann, J. Campisi, and R. Schlegel. 1993. Modulation of cell growth, p34cdc2 and cyclin A levels by SV-40 large T antigen. Oncogene 8: 2987-2993.

Pagano, M., R. Pepperkok, F. Verde, W. Ansorge, and G. Draetta. 1992. Cyclin A is required at two points in the human cell cycle. EMBO T. 11: 961-971.

Polyak, K., J.Y. Kato, M.J. Solomon, C.J. Sherr, J. Massague, J.M. Roberts, and A. Koff. 1994. p2 $7^{\mathrm{Kip1}}$, a cyclin-Cdk inhibitor, links transforming growth factor-beta and contact inhibition to cell cycle arrest. Genes \& Dev. 8: 9-22.

Raff, M.C., R.H. Miller, and M. Noble. 1983. A glial progenitor cell that develops in vitro into an astrocyte or an oligodendrocyte depending on culture medium. Nature 303: 390-396.

Ridley, A.J., H.F. Paterson, M. Noble, and H. Land. 1988. Rasmediated cell cycle arrest is altered by nuclear oncogenes to induce Schwann cell transformation. EMBO J. 7: 1635-1645.

Rudolph, B., R. Saffrich, J. Zwicker, B. Henglein, R. Muller, W. Ansorge, and M. Eilers. 1996. Activation of cyclin-dependent kinases by Myc mediates induction of cyclin A, but not apoptosis. EMBO /. 15: 3065-3076.

Samuels, M.L., M.J. Weber, J.M. Bishop, and M. McMahon. 1993. Conditional transformation of cells and rapid activation of the mitogen-activated protein kinase cascade by an estradiol-dependent human Raf-1 protein kinase. Mol. Cell. Biol. 13: 6241-6252.

Serrano, M.L., L.E. Gomez, R.A. DePinho, D. Beach, and S.D. Bar. 1995. Inhibition of ras-induced proliferation and cellular transformation by p16INK4. Science 267: 249-252.

Serrano, M., H.-W. Lee, L. Chin, C. Cordon-Cardo, D. Beach, and R.A. DePinho. 1996. Role of the INK4a locus in tumor suppression and cell mortality. Cell 85: 27-37.

Slingerland, J.M., L. Hengst, C.H. Pan, D. Alexander, M.R. Stampfer, and S.I. Reed. 1994. A novel inhibitor of cyclinCdk activity detected in transforming growth factor betaarrested epithelial cells. Mol. Cell. Biol. 14: 3683-3694.

Steinman, R.A., B. Hoffman, A. Iro, C. Guillouf, D.A. Liebermann, and M.E. el-Houseini. 1994. Induction of p21 (WAF1/CIP1) during differentiation. Oncogene 9: 3389-3396.

Toyoshima, H. and T. Hunter. 1994. p27, a novel inhibitor of G1 cyclin-Cdk protein kinase activity, is related to $\mathrm{p} 21$. Cell 78: 67-74.

Tsai, L.H., E. Lees, B. Faha, E. Harlow, and K. Riabowol. 1993. The cdk2 kinase is required for the G1-to-S transition in mammalian cells. Oncogene 8: 1593-1602.

Van Aelst, L., M. Barr, S. Marcus, A. Polverino, and M. Wigler. 1993. Complex formation between RAS and RAF and other protein kinases. Proc. Natl. Acad. Sci. 90: 6213-6217.

van den Heuvel, S. and E. Harlow. 1993. Distinct roles for cyclin-dependent kinases in cell cycle control. Science 262: 2050-2054.

Vlach, J., S. Hennecke, K. Alevizopoulos, D. Conti, and B. Amati. 1996. Growth arrest by the cyclin-dependent kinase inhibitor $27^{\text {Kip } 1}$ is abrogated by c-Myc. EMBO I. 15: 65956604.
Vojtek, A.B., S.M. Hollenberg, and J.A. Cooper. 1993. Mammalian Ras interacts directly with the serine/threonine kinase Raf. Cell 74: 205-214.

Vojtesek, B., J. Bartek, C.A. Midgley, and D.P. Lane. 1992. An immunochemical analysis of the human nuclear phosphoprotein p53. New monoclonal antibodies and epitope mapping using recombinant p53. I. Immunol. Methods 151: 237244.

Waldman, T., K.W. Kinzler, and B. Vogelstein. 1995. p21 is necessary for the p53-mediated G1 arrest in human cancer cells. Cancer Res. 55: 5187-5190.

Warne, P.H., P.R. Viciana, and J. Downward. 1993. Direct interaction of Ras and the amino-terminal region of Raf- 1 in vitro. Nature 364: 352-355.

Winston, J.T., S.R. Coats, Y.Z. Wang, and W.J. Pledger. 1996. Regulation of the cell cycle machinery by oncogenic ras. Oncogene 12: 127-134.

Wood, K.W., H. Qi, G. D'Arcangelo, R.C. Armstrong, T.M. Roberts, and S. Halegoua. 1993. The cytoplasmic raf oncogene induces a neuronal phenotype in PC12 cells: A potential role for cellular raf kinases in neuronal growth factor signal transduction. Proc. Nat1. Acad. Sci. 90: 5016-5020.

Xiong, Y., G.J. Hannon, H. Zhang, D. Casso, R. Kobayashi, and D. Beach. 1993. p21 is a universal inhibitor of cyclin kinases. Nature 366: 701-704.

Xu, G.F., B. Lin, K. Tanaka, D. Dunn, D. Wood, R. Gesteland, R. White, R. Weiss, and F. Tamanoi. 1990a. The catalytic domain of the neurofibromatosis type 1 gene product stimulates ras GTPase and complements ira mutants of S. cerevisiae. Cell 63: 835-841.

Xu, G.F., P. O'Connell, D. Viskochil, R. Cawthon, M. Robertson, M. Culver, D. Dunn, J. Stevens, R. Gesteland, R. White, and et al. $1990 \mathrm{~b}$. The neurofibromatosis type 1 gene encodes a protein related to GAP. Cell 62: 599-608.

Zhang, H., G.J. Hannon, and D. Beach. 1994. p21-containing cyclin kinases exist in both active and inactive states. Genes \& Dev. 8: 1750-1758.

Zindy, F., E. Lamas, X. Chenivesse, J. Sobczak, J. Wang, D. Fesquet, B. Henglein, and C. Brechot. 1992. Cyclin A is required in $\mathrm{S}$ phase in normal epithelial cells. Biochem. Biophys. Res. Commun. 182: 1144-1154. 


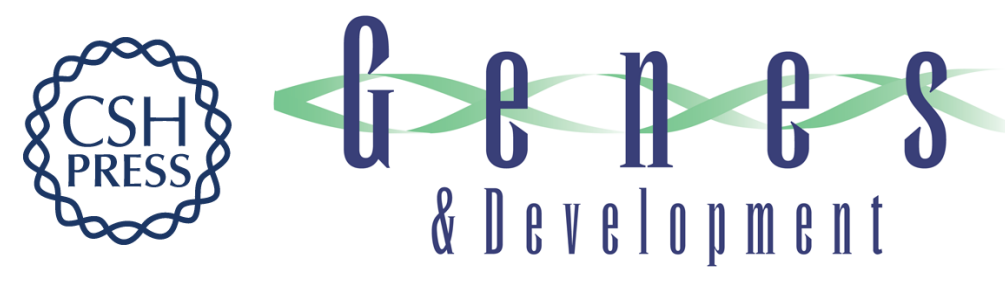

\section{Cooperating oncogenes converge to regulate cyclin/cdk complexes.}

A C Lloyd, F Obermüller, S Staddon, et al.

Genes Dev. 1997, 11:

Access the most recent version at doi:10.1101/gad.11.5.663

References This article cites 73 articles, 27 of which can be accessed free at: http://genesdev.cshlp.org/content/11/5/663.full.html\#ref-list-1

License

Email Alerting Receive free email alerts when new articles cite this article - sign up in the box at the top Service right corner of the article or click here.

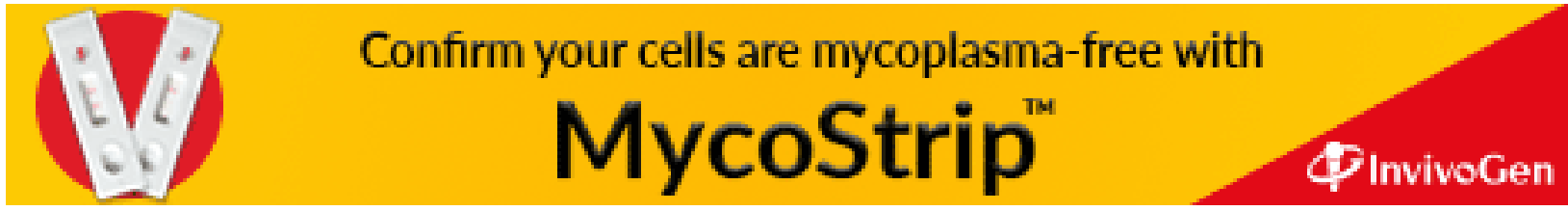

